\title{
Did Joshua Reynolds Paint His Pictures? The Transatlantic Work of Picturing in an Age of Chymical Reproduction
}

In the spring of 1787 , King George III visited the Royal Academy of Arts at Somerset House on the Strand in London's West End. The king had come to see the first series of the Seven Sacraments painted by Nicolas Poussin (1594-1665) for Roman patron Cassiano dal Pozzo in the later 1630s. It was Poussin's Extreme Unction (ca. 1638-1640) (fig. 1) that won the king's particular praise. 'Below a coffered ceiling, Poussin depicts two trains of mourners converging in a darkened interior as a priest administers last rites to the dying man recumbent on a low bed. Light enters from the left in the elongated taper borne by a barefoot acolyte in a flowing, scarlet robe. It filters in peristaltic motion along the back wall where a projecting, circular molding describes somber totality. Ritual fluids proceed from the right, passing in relay from the cerulean pitcher on the illuminated tripod table to a green-garbed youth then to the gold flagon for which the central bearded elder reaches, to be rubbed as oily film on the invalid's eyelids.

Secured for twenty-first century eyes through a spectacular fund-raising campaign in 2013 by Cambridge's Fitzwilliam Museum, Poussin's picture had been put before the king in the 178 os by no less spirited means. Working for Charles Manners, fourth Duke of Rutland, a Scottish antiquarian named James Byres had Poussin's Sacraments exported from Rome and shipped to London where they were cleaned and exhibited under the auspices of Royal Academy President Sir Joshua Reynolds (1723-1792).2 If less flashy than his 


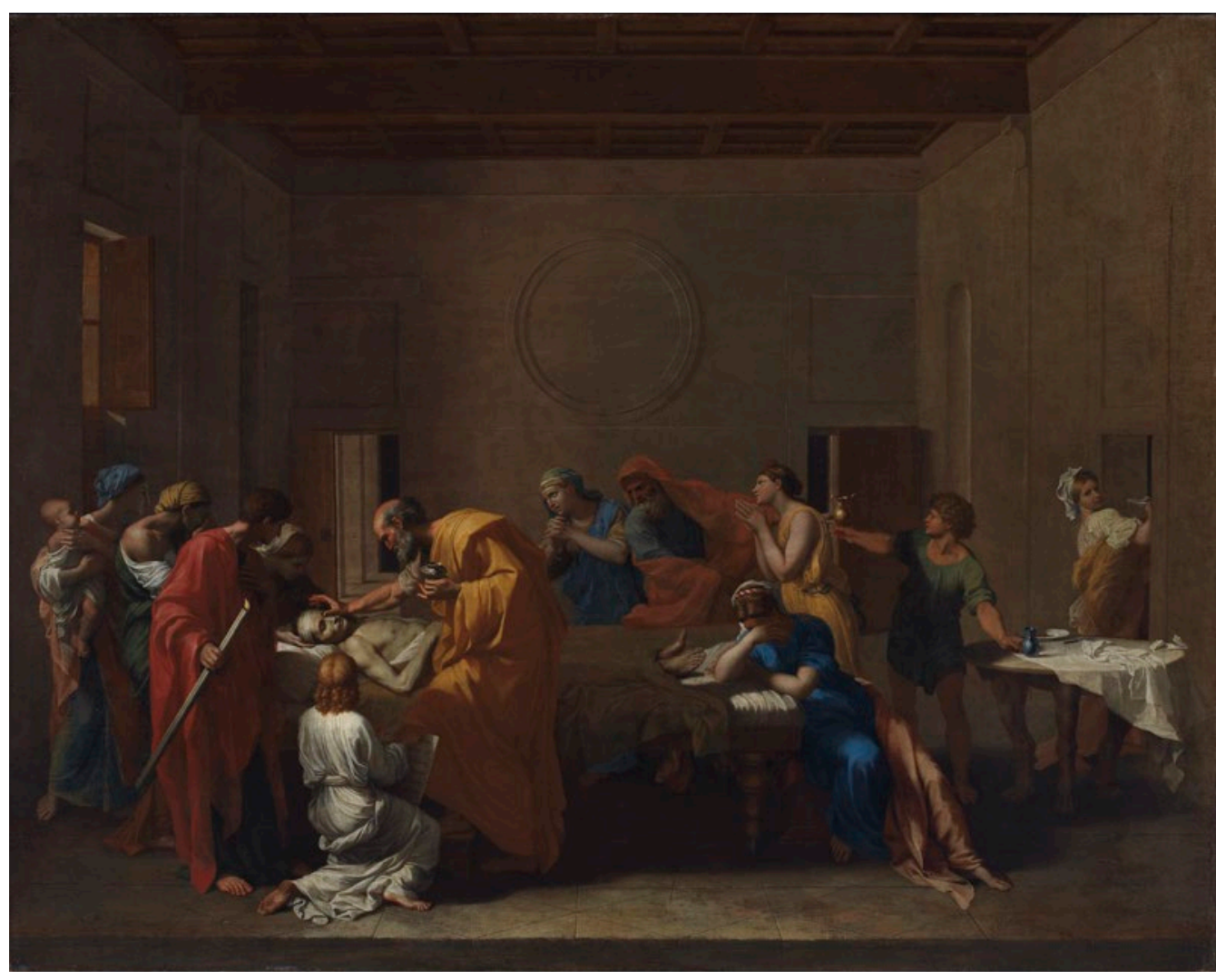
Nicolas Poussin, L'Extrême-Onction (Extreme unction), ca. $1638-1640$. Oil on canvas, $37^{5 / 8} \times 47^{5 / 8}$ in $(95.5 \times 121 \mathrm{~cm})$. The Fitzwilliam Museum, Cambridge, United Kingdom

2 "Sir Joshua Reynolds Helped to Pirate Old Masters," New York Times Sunday Magazine Feb. 1, 1914, 1. earlier sale of the Portland Vase to Sir William Hamilton, Byres's coup is worthy of note nonetheless. ${ }^{3}$ On the pretense of having the Poussin Sacraments cleaned in Rome, Byres removed the pictures from the Boccapaduli Palace one by one. Surreptitiously replacing them with replicas painted by a Fleming named André de Muynck, he shipped the originals off to the president in London. Anticipating receipt of those canvases, Reynolds assured Rutland that Byres's scheme was just as time-tested as it was readily replicable: "It is very probable [that] those copies will be sold again and other copies put in their place. This trick has been played with Pictures of Salvator Rosa by some of his descendants ... who pretend that the Pictures have been in the family ever since their ancestor's death." 4 In an age that would soon see the removal of the Parthenon sculptures and their installation in the British Museum as the "Elgin Marbles," Reynolds was unmoved by any talk of pictorial malfeasance. As he put it to Rutland: "I have not the least scruple about sending copies for originals." 5

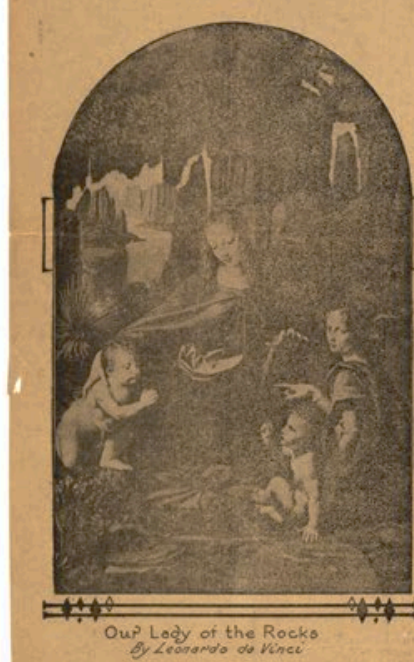

His Letters, Just Found, Show He Was Involved in Substitutinè Copies for Orièinals. $\mathrm{L}= \pm \equiv= \pm=$

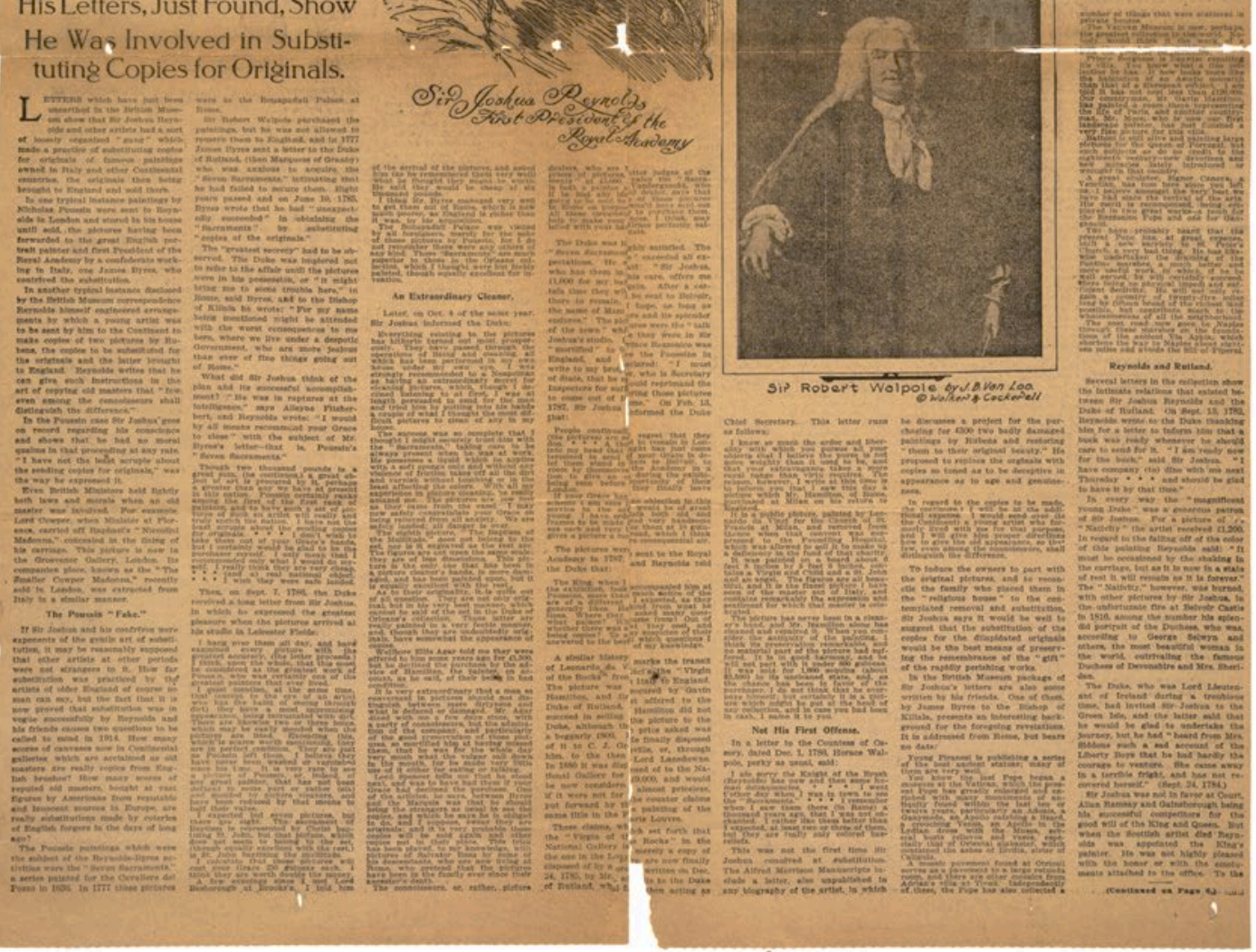


Rediscovered in the early twentieth century, however, the Reynolds-Rutland correspondence was viewed differently by American readers. Writing in 1914 from the epicenter of an exploding market for European art driven by J. P. Morgan, Henry Clay Frick, and other "robber baron" collectors, a screaming headline from the New York Times named the crime: "Sir Joshua Reynolds Helped to Pirate Old Masters." Poised above the newspaper's horizontal fold, a bespectacled Reynolds gazes out from a ground of lithographic striations, his nervously hatched body plotted among those Italian masterpieces he had purportedly helped traffic (fig. 2). ${ }^{6}$ For the Times' unnamed writer such familiar comportment forced "two questions to be called to mind in 1914. How many scores of canvases now in Continental galleries which are acclaimed as old masters are really copies from English brushes? How many scores of reputed old masters, bought at vast figures by Americans from reputable and innocent sources in Europe, are really substitutions made by coteries of English forgers in the days of long ago?"7

Asked amid the transatlantic politics of art on the cusp of the First World War, this essay's titular question might thus have been interpreted as an inquiry after property and propriety. Was Reynolds involved somehow in a shady business of painting and dealing pictures not truly his own? 8 In fact, queries after Reynolds's fair dealing are not only older but more vexingly intricate. In his period biography of the president, critic Edmond Malone dismissed as "too ridiculous and absurd to be gravely confuted" the charge that poet Dr. Samuel Johnson (1709-1784) had written the famous Discourses on Art, which Reynolds delivered semiannually at the academy's prize-giving ceremony. ${ }^{9}$ Nevertheless, Malone then went on to quash a different rumor, one claiming that politician and theorist Edmund Burke was the Discourses' author. ${ }^{10}$ And Reynolds hardly did himself any favors in those famous discourses where he positively embraced theft as a Promethean act at the very core of ambitious art. "Borrowing or stealing," as he put it in "Discourse VI" from December 1774, should be regarded with the same lenience among painters "as was used by the Lacedemonians; who did not punish theft, but the want of artifice to conceal it." II Indeed, the period's liveliest accusation of the president's light-handed turpitude followed directly on the heels of that 1774 discourse. In the spring of 1775 , Irish painter Nathaniel Hone (17181784) submitted to the Royal Academy's summer exhibition The Pictorial Conjuror, displaying the Whole Art of Optical Deception (fig. 3). ${ }^{12}$ Seen here in oil sketch on wood panel, Hone depicts a bearded
Nathaniel Hone, Sketch for "The Conjuror," 1775 Oil on wood, $225 / 8 \times 32$ $1 / 4 \mathrm{in} .(57.5 \times 81.9 \mathrm{~cm})$. Tate Gallery, London, Toog38.

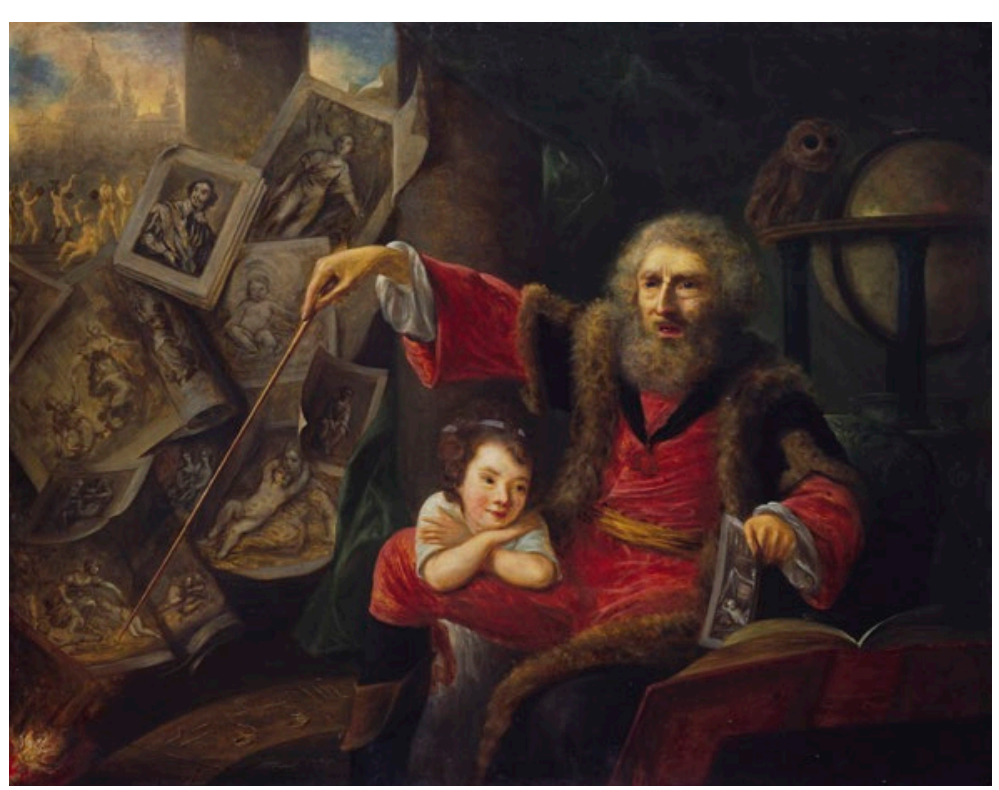

figure (identifiable to contemporaries as George White, a model favored by Reynolds) cloaked in a crimson housecoat and fur-lined vest, a hexagram pendant dangling from his neck. The action of the picture is directed down the conjuror's wand. Buffeted in by an arch inscribed with zodiacal symbols, our eyes are guided diagonally from the darkened globe and owl at upper right to the site of combustion at left where fire leaps forth under magical command to consume cascade of copperplate prints after Old Master pictures. Initially accepted for exhibition, Hone's Pictorial Conjuror was quickly rejected once disclosed as a satire variously impugning the virtue of academician Angelica Kaufman and the borrowing underpinning Reynolds's emulation of the Old Masters. Where Horace Walpole's then-recent, fourth installment of Anecdotes of Painting in England (1771) defended the president's numerous references to art's history as "not plagiarism, but quotation," painter Joseph Farington cast the scene more darkly. ${ }^{13}$ Hone's picture was contrived, he observed, to show that Reynolds "had no power of invention; that he was a decided plagiarist; and that his designs for groups of figures, and of attitudes for his portraits, were stolen, as it was termed, from prints." 14

Passing copies for original pictures and profiting from designs not really his to paint, Reynolds begot still more searching questions on the nature of pictorial existence - of picturing - itself. A year and a half 
before his "Discourse vI," an anonymous contributor to the Morning Chronicle and London Advertiser articulated that problem in an

open letter addressed to Reynolds. ${ }^{15}$ Paint's unctuous, chromatic ooze, this anonymous critic charged, had come to color British art with an untoward, defacing stain. The issue was partly a linguistic one, since it followed from the practice of denoting British picture makers through an excessively literal translation of French words. In typical English parlance, Peintre became "Painter, and the materials which ingenious persons of that denomination make use of to display their talents, we

have, from that word, called paint, which in French is named coleurs." 16 Where the French salubriously bifurcated their lexical designation of artist from materials (Peintre and coleurs), English speakers compressed them together. ${ }^{17}$ In the wake of Britain's resounding defeat of the French in the Seven Years' War (1756-1763), the Morning Chronicle writer proposed a solution that would throw off Gallic linguistic hegemony and clearly distinguish the fine artist from "he who makes use of paint to cover walls and houses with." 18 Appealing to the antique tastes of Reynolds's classicizing circles, the writer asks:

"Why not like sculptors and architects have a peculiar name, Sir Joshua, for your very profession? Why not like these take up at once your classic name? Why not Pictor?" 19

Pictor is from the Latin verb pingere, "to paint," a root that yields in turn pictura, the act of painting or its product, a picture. What, then, is a picture? And how is it to relate to the paints manipulated by this Pictor? Grounded in Reynolds's milieu but trafficking in far older currents, the Morning Chronicle writer's impulse to privilege pictures above their constitutive physical supports forces forward an issue with abiding salience for the interpretation of Anglo-American art. ${ }^{20}$ If James Elkins is correct that, for contemporary theorists of all stripes, talk of pictures sustains a dream "that there is such a thing as a purely visual artifact independent of writing or other symbolic means of communication," recognizing the relation between picture and its material thingness as a site of meaning has been crucial to interpreters of the Modernist tradition and its early modern roots. ${ }^{21}$ Staring down the incursion of literally shaped canvases into New York School abstraction of the early 196os, Michael Fried envisioned a complex engagement between picture and painters' materials forced by the opticality of postpainterly abstraction. In the irregular polygons of Frank Stella (b. 1936) (fig. 4), Fried saw painting surviving the material allure of the shaped canvas by insisting on being pictorial. "By making literalness illusive," Fried wrote in 1966, Stella’s paintings triumphed

insofar as they dissolved the apparent "conflict between a particular kind of pictorial illusionism - addressed to eyesight alone - and the literal character of the support." 22

Taking a different approach in his Languages of Art (1968), philosopher Nelson Goodman defined pictures by their inexhaustible fullness, their "repleteness." 23 Possessed of potentially infinite gradations within their symbolic markings - pointing to indeterminate targets in the world, or to none at all - pictures for Goodman were syntactically and semantically dense, replete signs wherein everything potentially counts: "any thickening or thinning of the line, its size, even the qualities of the paper-none of these is ruled out, none of these can be ignored." 24 Recent materialist approaches to AngloAmerican art have restaged these modernist debates in a knowingly savvy way. Jennifer Roberts's work on American colonial painter John Singleton Copley (1738-1815) explicitly radicalizes the ambit of Goodman's pictorial conception. "The theorist Nelson Goodman wrote in 1968," she observes, "that "such properties as weighing ten pounds or being in transit from Boston to New York on a certain day hardly affect the status of a painting in its representational scheme." 25 But Roberts expands the envelope of meaning to include those Frank Stella,

Effingham I, 1967 Acrylic on canvas, $1283 / 4 \times 132 \times 4$ in. $(327 \times$ $335.5 \times 10.1 \mathrm{~cm})$. Van Abbemuseum Eindhoven,

The Netherlands, $45^{8}$.

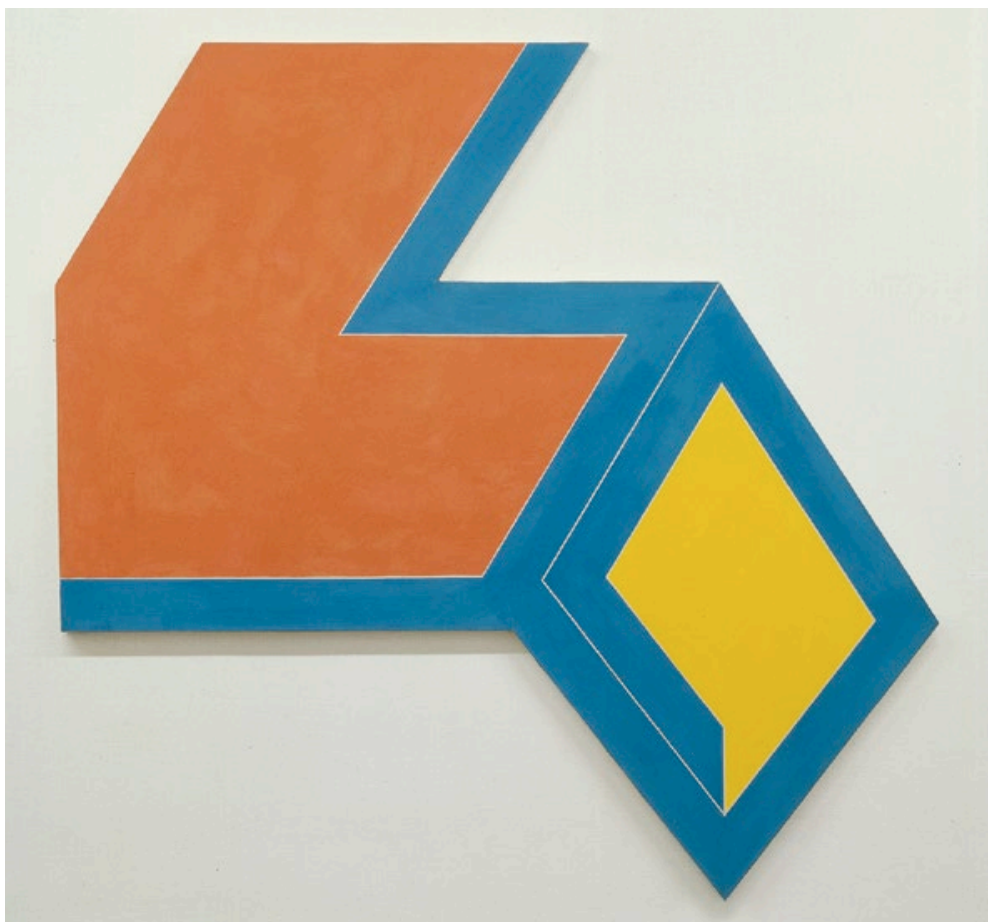


worldly logistics. The pictorial significance of Copley's A Boy with a Flying Squirrel (Henry Pelham) (1765) becomes inseparable from the fact that it was designed as a material thing to be sent by ship from Boston to London where it could be seen by viewers including

Reynolds: "weight and time and transit pervade Copley's painting not only in its configuration but also in its design and iconography." 26

Although made obliquely, Roberts's engagement with Fried's reading of picture and shape is no less compelling here. ${ }^{27}$ Refusing compression with the physical terms of the paint support, modernist painting had survived for Fried insofar as it maintained autonomous self-enclosure in pictorial fiction, a problematic his own subsequent

art-historical writing has traced forward from the eighteenth century. ${ }^{28}$ In turn, following her first book on Robert Smithson (a deft critic of

Fried's modernism), Roberts too has moved to the eighteenth century, but to read pictorial surfaces as effectively swamped by what Smithson had sarcastically called "this 'harrowing" of hellish objecthood [that] is causing modernity much vexation and turmoil." 29

I will return to these terms of contemporary debate in my conclusion, but the Morning Chronicle writer implicitly foregrounds the crucial, historical point: nowhere in eighteenth-century Anglo-American art were issues of pictorial ontology more devilishly complicated than in the works of Joshua Reynolds himself. At once, qua picture, Reynolds's Diana (Sackville), Viscountess Crosbie (1777) (fig. 5) could be said to comprise a dense, Goodmanian symbol-system whose syntax describes an infinitude of meaningful marks. By one reading, those marks make for a stunning exercise in portraiture. Gazing cherubically out from the picture plane, Crosbie cinches the train of her shimmering cream dress and steadies herself against a breeze that tousles her voluminous hair into whirling ringlets. Its sylvan frame opening onto an azure pane of sky, this portrait's semantic field denotes as much Diana Sackville as it does Reynolds's earlier Mrs. Hale as 'Euphrosyne' (1762-1764) (fig. 6), now at Harewood House in Yorkshire. 30 Yet thanks to his inveterate experiments with paint chemistry, Reynolds's pictures were frequently menaced by their material existence as objects - as painted things inclined to fade, to flake, and to alter visibly in time. Among Reynolds's contemporaries, these volatilities were the stuff of legend. The Royal Academy president's coloring, so wrote one French observer in the early nineteenth century, "fades away, and disappears rapidly;-many of his pictures are now only black and white. He is said to have been fond of trying experiments in colors, and thought he had found the secret of rendering them more lasting." 31 Poet William

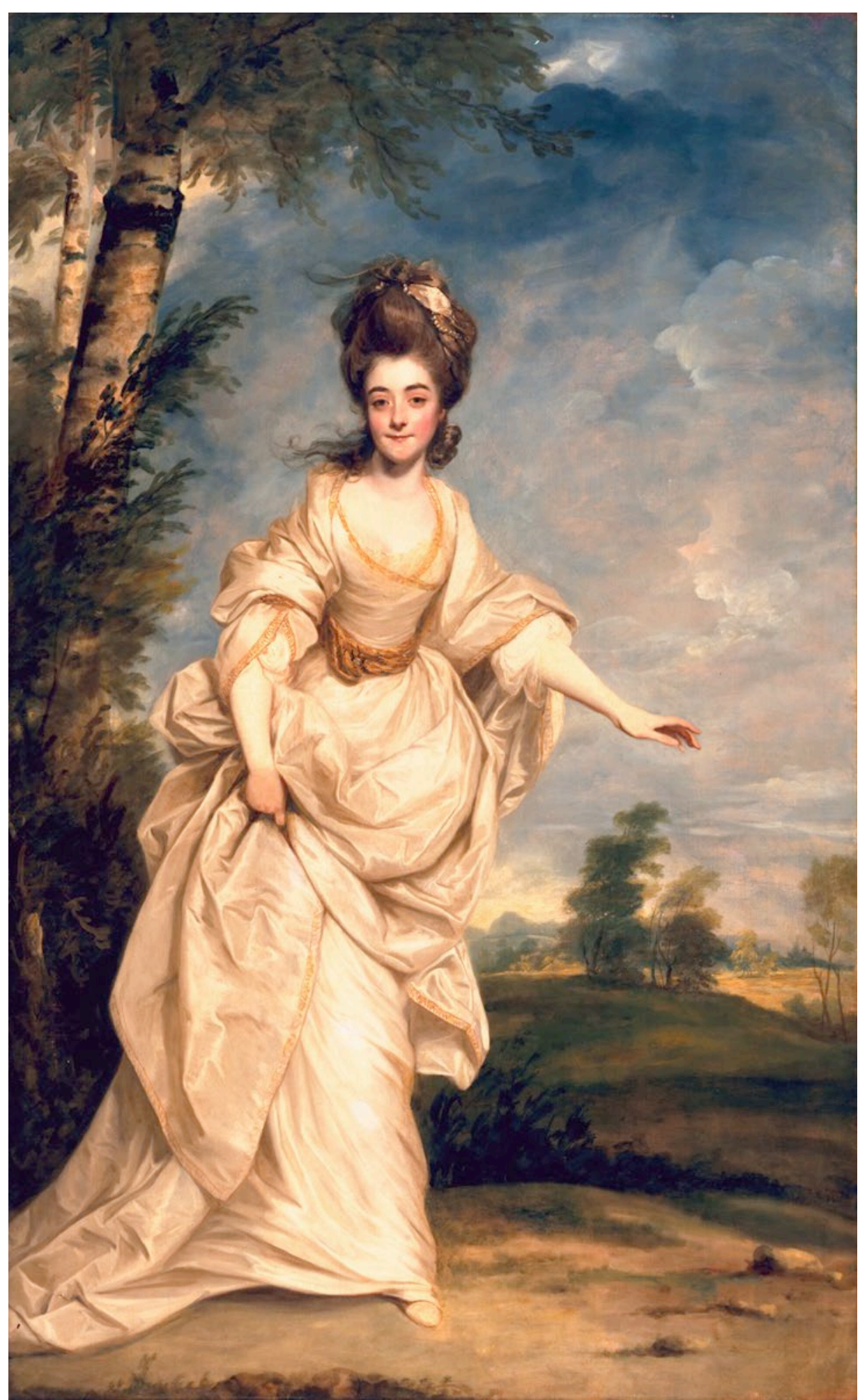


Repair report on Diana (Sackville), Viscountess Crosbie, ca. 1990 s. The Huntington Library Art Collections, and Botanical Gardens, San Marino, California.

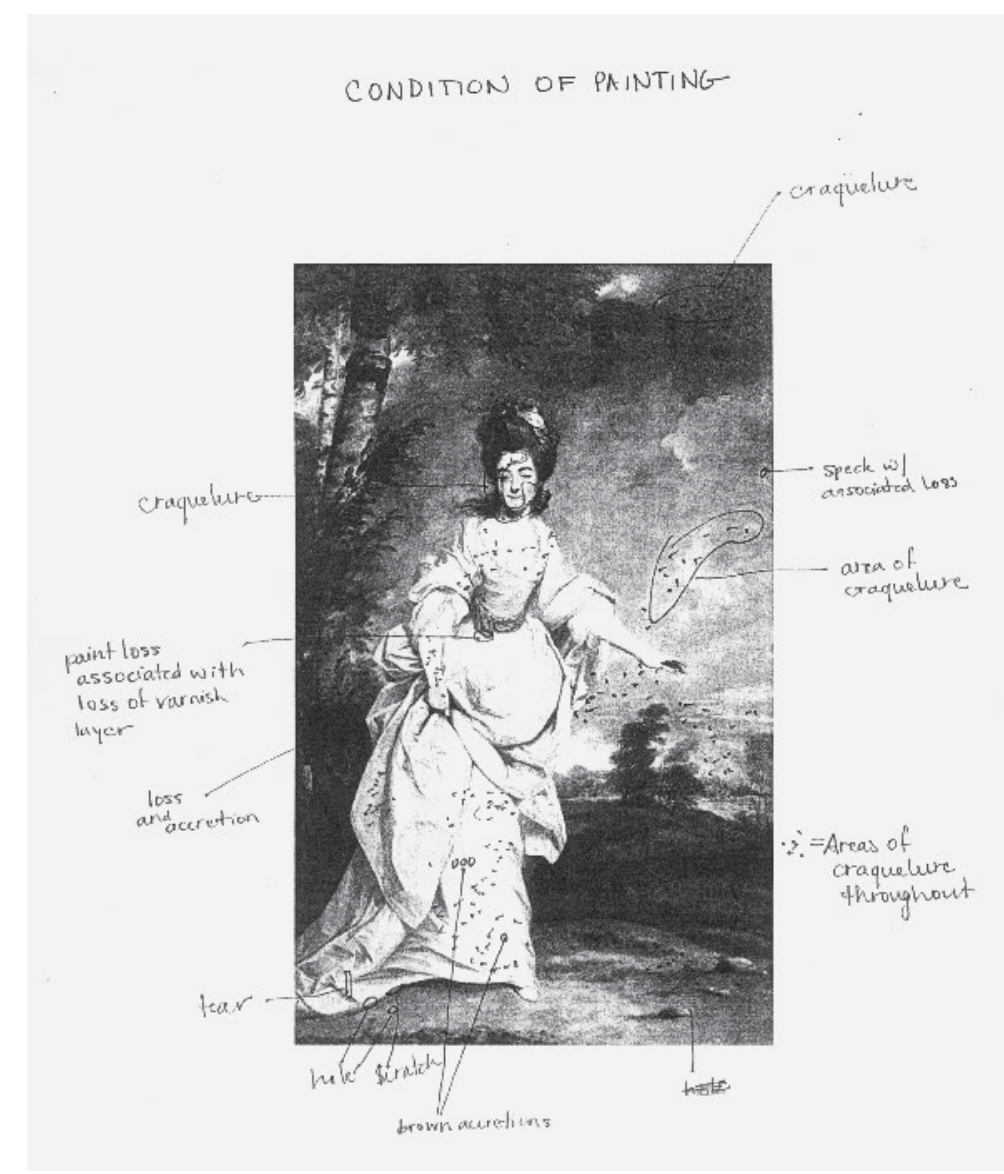

Mason recalled an infamous episode when Reynolds eagerly bought from "some itinerant foreigner ... a parcel of what he pretended was genuine ultramarine, which, in point of color, seemed fully to answer its title. Without bringing it to any chemical test, the artist ventured to use it, and by it spoiled, as he assured me, several pictures." $32 \mathrm{~A}$ "poetical epistle" addressed to Reynolds in 1777 envisioned those changes as unfolding in real time: "As I thus enraptur'd stand / Before the wonders of your hand, / I see the lively tints decay, / The vivid colours melt away." 33 Modern technical historian Mansfield Kirby Talley has summarized the situation most succinctly. Reynolds's "persistence in following practices which he knew perfectly well would seriously shorten the life of his pictures can only be described as perverse." 34

Given the searing impression made on Copley, Benjamin West (1738-1820), and other ambitious American artists by what Neil Harris has called the "vast moral function" staked out in Reynolds's fabulously successful art, this essay aims to thematize that "perverse" relationship between the material chemistry of paint and pictorial function - between pigments and picturing - as a key problem for Anglo-American art of the late eighteenth century. 35 To that end, the essay unfolds in two stages. First, building from the Morning Chronicle's lexical query, I use the insights of Dr. Samuel Johnson (eminent linguist of Reynolds's erudite circles) to pose the problem of pictorial ontology against the numerous replicative media through which the president's unstable paintings were then made available to transatlantic audiences. Since pictures in this view cannot be reduced to paint and indeed were imagined to persist long after the unstable material artifact had decayed, a first answer to the essay's titular question is negative. Reynolds did not paint his pictures, and perhaps could not have done so. A second approach to the question then turns the problem around. I will attend to the variety of forces understood to be not only active at the making of Reynolds's images but valued for their ongoing, material evolutions within his works. Seeing the Reynoldsian Pictor as never alone when he painted best enables us to reconcile the president's theory of art set out in the Discourses with his experimental facture. Doing so, I will argue, not only foregrounds the centrality of his vexing pictorial problematic to ontological questions now most frequently associated with the art of photography, but it can also help us imagine anew a Reynoldsian legacy in a tradition of American-born experimental painters including West, Washington Allston, and Albert Pinkham Ryder. ${ }^{36}$

\section{Painting as a History of Metals}

Reynolds's former apprentice James Northcote (1746-1831) recounts a tale in his period biography designed to demonstrate Samuel Johnson's ignorance of visual art. Dismayed to see "so much mind as the science of painting requires, laid out upon such perishable materials," the poet asks Reynolds at a gathering in 1771 why painters did not prefer copper to canvas as a pictorial support. ${ }^{37}$ Johnson here effectively performs that collapsing of picture into paint materials so displeasing to the Morning Chronicle writer. After all, the poet had defined "picture" in his 1755 Dictionary as "a resemblance of persons or things in colours." Only in secondary and tertiary definitions did picture appear as a body of knowledge ("the science of painting," then "the works of painters") properly separating intellectual skill from staining matter. ${ }^{38}$ And that chromaticist, materialist conception of picture 
shows through in the 1771 conversation with Reynolds and wealthy brewer Henry Thrale. As Reynolds deflects the poet's promotion of copper supports by gesturing to the difficultly in sourcing sufficiently large plates of metal, Johnson cuts him short: "What foppish obstacles are these! ... Here is Thrale who has a thousand ton of copper; you may paint it all round if you will, I suppose. It will serve to brew in afterwards: will it not, Sir?" 39

Paltry though Northcote claims Johnson's knowledge of the visua to be, painting on copper was indeed an art perfected in early modern Europe. As a support, it offered what one recent scholar has called a "smoother and more uniform surface, ideal for working with fine brushes." 40 Variations on that technique were being developed in the early 1770 s by Joseph Wright of Derby (like Reynolds, a product of Thomas Hudson's studio) to achieve brilliantly luminous effects. In pictures such as Two Boys by Candlelight (ca. 1767-1773) (fig. 7),

Wright applied silver leaf onto those areas of the canvas that were to read as most luminous, so that light would reflect off the metal support and show back through the paint layer as the bladder's diffused glow. ${ }^{41}$ In so doing, Wright also compromised the integrity of the "science of painting" Johnson had sought to safeguard. Where his collaborator Peter Perez Burdett quickly rendered that chiaroscuro scene in aquatint and exhibited it as "the effect of a stained drawing attempted, by printing from a plate wrought chemically, without the use of any instrument of sculpture" in early 1770s London, Wright's own intersection of paint chemicals and metal has fared poorly. 42 His glowing bladder's veinous structure has flaked into pictorial oblivion.

If not the practical panacea Johnson imagined, metallic supports offered Northcote a broader meditation on pictorial ontology. Reynolds's apprentice chided Johnson for failing to recognize "that the duration of a picture does not depend on the strength or durability of the canvas on which is it painted. The canvas can be renewed as often as it may be found necessary, and the colours will in time become nearly as hard and as durable as enamel. It is by frequent and injudicious cleaning, and not by time, that pictures are destroyed." 43 Suggesting what philosophers call the ship of Theseus problem, Northcote envisions the identity of a picture persisting through time even after aspects of its original, material composition had vanished. ${ }^{44}$ Pictorial ontology is reducible neither to the brute longevity of the canvas carrying the paint film nor to the mere endurance of unaltered pigments, binders, and other physical stuff of mark making. Canvas replaces canvas, oil paint becomes like enamel, but picture abides.

Writing in the wake of the British Institution's 1813 exhibition Pictures by the Late Sir Toshua Reynolds, painter Martin Archer Shee expanded on this distinction between material duration and pictorial durability. Shee acknowledged that "Reynolds at an early period of his practice, painted many pictures, which, from the failures incident to an experimental process, have not preserved their brilliancy." 45 Yet it was a foolish viewer who confused those frailties of experimental pigments with failed pictures. "The magnificent assemblage of his works so lately before the public," Shee observed, "did not indeed . . . excite the idea of 'a chemist's window.' The ambition of Reynolds was to produce fine colouring, not fine colours. His was the chastened glow - the subdued splendor - the 'deep toned brilliancy of the ancients;' which he so elegantly recommends in theory, and so successfully illustrates in practice." 46 Pictorial skill - that elusive, historical commodity

7 Joseph Wright of Derby Two Boys by Candlelight, Blowing a Bladde ca. $1767-1773$. Oil on canvas, $36 \times 283 / 8$ in $(91.4 \times 72.1 \mathrm{~cm})$. The Huntington Library, Art Collections, and Botanical Gardens, San Marino, California, 58.16 .

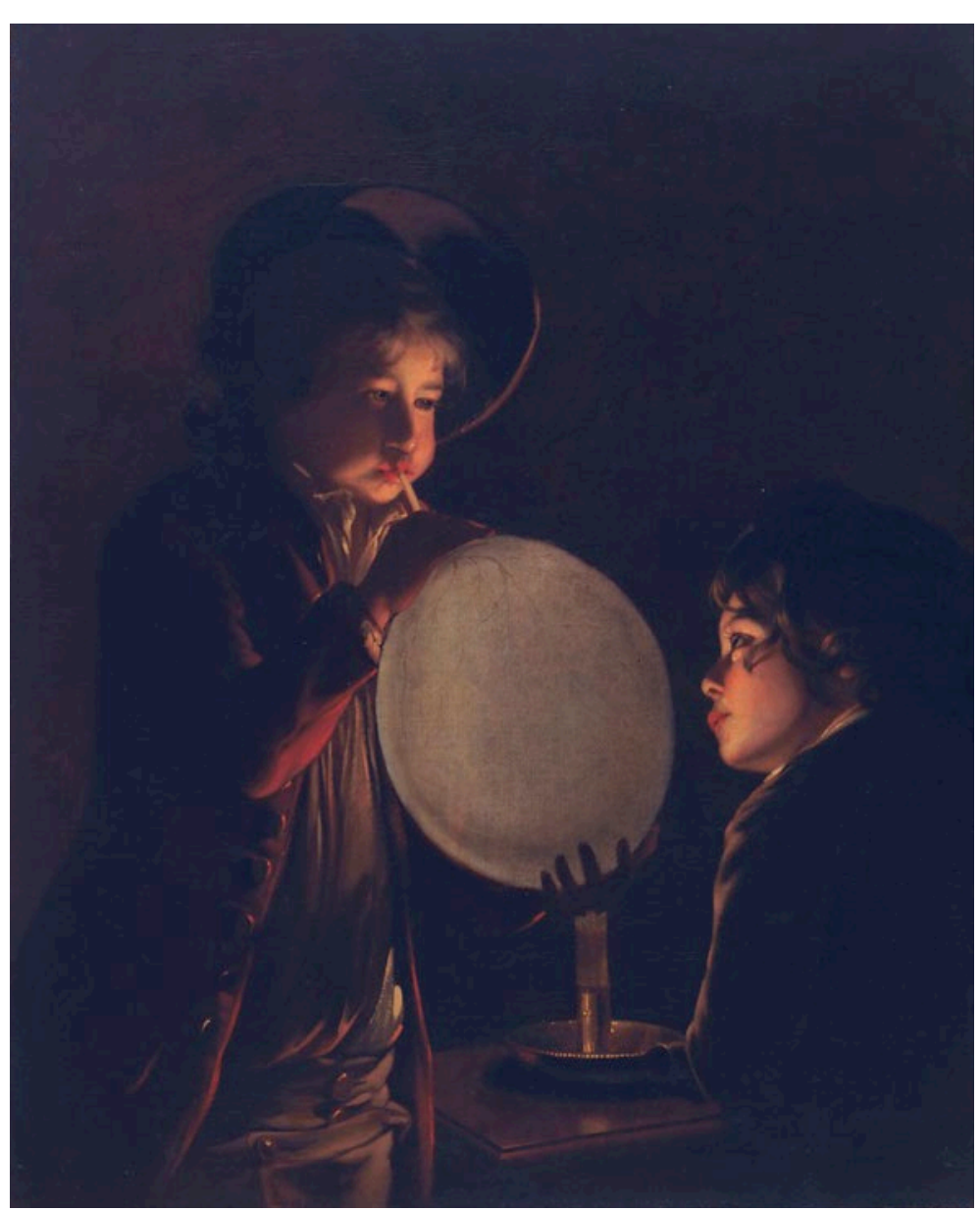


convincingly traced by Michael Baxandall rising up through and surpassing the value of material pigments in fifteenth-century Italian painters' contracts - is the criteria by which all but the coarsest philistine would, in Shee's view, evaluate Reynolds's work. 47

A still more radical implication of this splitting of picture from painted thing was posed by Reynolds himself. According to J. T. Smith "Sir Joshua Reynolds considered the art of mezzotint as best calculated to express a painter-like feeling. I have often heard him declare, that the productions of M'Ardell would perpetuate his pictures when their colours should be faded and forgotten." 48 That is, James Macardell's "painter-like" mezzotint engravings would not only transmit Reynolds's decaying colors and their unstable canvas supports to posterity, but they would do so precisely by transposing paint into what Smith calls "pictures." In this sense, Joshua Reynolds did not paint his pictures at all for the simple reason that pictures were not-and perhaps could not be-painted in the conventional sense. Instead, painted things became pictures when detached from an unstable, autograph materialization and transposed into reproductive, copperplate multiplicity. More than it being Reynolds who painted his pictures, we might say, it was engraver James Macardell who pictured Reynolds's paintings.

Further, to return to the Morning Chronicle writer's terms, the Anglophone Pictor modeled here appears to have stolen a march on a much-maligned ancestor, the Platonic zographos. As Plato had argued in The Republic, a carpenter or other skilled craftsman (demiourgos) fashions a bed or table by referring back to the idea (eidos) of that artifact, which is made by god. ${ }^{49}$ The painter (zographos), however, makes neither the idea nor its material incarnation. Instead, he copies the craftsman's physical realization of the divine idea, thus placing his work at three removes from the true nature of things (ton tou tritou apa gennematos apo tes phuseos mimeten).50 The Reynoldsian Pictor, by contrast, creates a skillful idealization that outstrips and outlasts its own material frailties precisely as it is perpetuated pictorially by subservient craftsmen.

In this way, the parsing of picturing from painting accords well with the broader academic enterprise promoted under Reynolds. By separating itself from the messy business of paint handling, the Royal Academy's artistic pedagogy had foregrounded appeal to the stable, persistent virtues of Florentine disengo over the fugitive, ephemeral allures of Venetian colorito - sentiments found frequently in the president's Discourses. ${ }^{51}$ At the same time, Reynolds's own use of reproductive technologies to disseminate his paintings was as
8

Benjamin West, Angel of the Resurrection, 801. Lithograph, $123 / 8 \times$ $87 / 8$ in. $(31.4 \times 22.5 \mathrm{~cm})$. Yale University Art Gallery, New Haven, Connecticut, 1955.18.22.

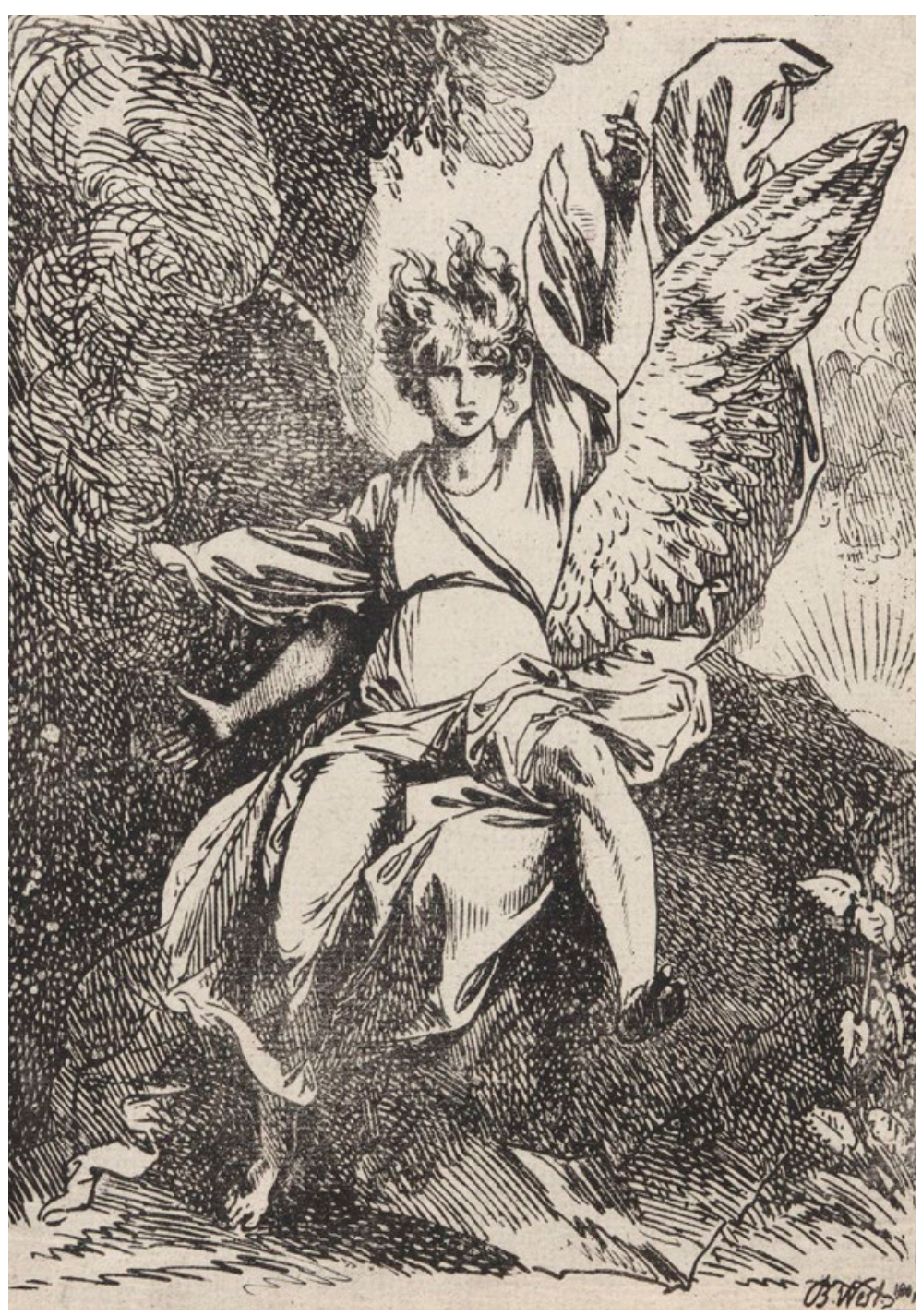

sophisticated as it was vast. Contracting with generations of mezzotint engravers including Macardell (1727/8-1756), Valentine Green (1739-1813), and John Raphael Smith (1751-1815), the president famously "kept a port-folio in his painting-room, containing every print that had been taken from his portraits; so that those who came to sit, had this collection to look over, and if they fixed on any particular attitude ... he would repeat it precisely." 52 In light of the pioneering research of Waldron Belknap, this panoply of British mezzotints has been described as a focalizing force in shaping American pictorial tradition, "the major factor in transmitting fashion, feeling, art 
traditions and all the pictorial elements of Old World culture to the New." 53 Yet if it is true that "no other artist was more frequently copied" in the mezzotint printer's copper than Reynolds, I argue in the following section that a novel array of experimental reproductive techniques would equally enfold the president's metallic memorialization into chemical circulation. ${ }^{54}$ That is, the chemical arts of lithography, pollaplasiasmos, and enamel can help us rethink the reproductive strategies central to the Anglo-American Reynoldsian Pictor.

\section{Chymical Reproduction}

With darkened palm and the shaded sole of an outstretched foot held aloft, Benjamin West's Angel of the Resurrection (1801) (fig. 8) stares directly out from the picture plane. Smoke curls in frothy billows from densely hatched darkness at left, its networked intensity of tone answering in counterpoint to the dotted arc and starburst rays of sunlight cresting the sloping hillocks at right. Split down the spine of the image through the licking flames of the angel's unevenly forked locks, West's intent figure appears strangely unsettled. Said better, the angel figures a conspicuous struggle for balance - a pursuit of equilibrium between the resplendent plumage of his proper left wing and its obscured twin, between the plant straining upward to find sunlight at right and the inky void at left. Light versus dark, sprouting life versus curling smoke: the image's various efforts at left-right reconciliation act to call attention to the massive boulder on which the angel sits so awkwardly. With splayed legs taking the stone's broad measure, the angel's perch compels us to tarry over that rock rolled back from the threshold of Christ's tomb to reveal his resurrection accomplished, perhaps. But it also alerts us to the force of stoniness in the making of the image. For, published in Philipp André's Specimens of Polyautography (1803), West's print is an early example of the art of lithography, a technique that had been invented by entrepreneurial printer Alois Senefelder between 1796 and 1798.55

According to Walter Benjamin, the advent of lithography marked a key contribution to the technological acceleration of image in the modern age. "The fact that the drawing is traced on a stone, rather than incised on a block or wood or etched on a copper plate," Benjamin observed, “... made it possible for graphic art to market its products not only in large numbers . . but in daily changing forms." 56 Narrated by contemporaries amid what historians of science call the "Chemical Revolution," however, Senefelder's practice was more a matter of chemistry than of technicshen Reproduzierbarkeit.57 "The ink is a chemical preparation," so one writer explained in an 1808 contribution to the Gentleman's Magazine, "of which soda, lac, and lamp-black are component parts." 58 Then known in France as imprimerie chimique, lithography turns on what one modern historian has called "very simple chemical principles: the antipathy of grease and water, and the attraction of these two substances to their like and to a common porous ground." 59 Given West's enmeshment in the delicious scandal of the "Venetian Secret" during the later 179os, the lithographic angel might well be seen as embodying a resurrection of chemical hopes and alchemical theology that the American painter shared with leading contemporaries in Britain. 60

Seen by his leading Victorian biographers, Joshua Reynolds too had to be counted in that chymical cult.61 "He believed in the Venetian secret as ever an alchymist did in the philosopher's stone," observe Charles Robert Leslie and Tom Taylor, "and so intense was his love of colour, that he would always hazard the durability of his works rather than give up any chance of attaining its truth and beauty." 62 Reynolds's robust interface with chymical techniques also extended to his replicators and their innovations. One of these is an invention known as pollaplasiasmos. In the $178 \mathrm{os}$, portrait painter and entrepreneur Joseph Booth (d. 1797) began a series of bombastic publications trumpeting his replication of grand manner oil paintings by "a mechanical and chymical process, without any touch or finishing by the hand." 63 Offering pollaplasiasmic reproductions of Reynolds's Girl Leaning on a Pedestal (The Laughing Girl) (ca. 1775-1782) for pennies on the pound from display rooms of the Polygraphic Society on

London's Pall Mall, Booth envisioned positively revolutionary benefits to flow once great art was placed in the hands of a general public through such cut-rate, high-quality reproductions. 64 "By reducing the price of commodities and manufactures," Booth proposed, pollaplasiasmos "multiplies customers, and extends their sale." 65 Drawing a telling analogy with "the invention of cotton mills ... in Lancashire," he cast his chemo-mechanization process not as an obstacle to the traditional painter's living, but rather as a means of rendering the art-market elastic by working to "cherish and diffuse a general taste for painting." 66

Public though his process would make the oil painter's products, Booth was highly secretive about his own technique. Replicating works such as Philippe Jacques de Loutherbourg's A Winter Morning, with a Party Skating (ca. 1776) (fig. 9), he appears to have fabricated a complex printing matrix for stenciling or stamping oil-painted form 
onto prepared canvases. Identifying the surprising presence of pumice mixed into Booth's thick priming layers, a recent technical study by David Saunders and Antony Griffiths supports the claims for pollaplasiasmos's chymical and mechanical agency. As the authors observe: "If the paint was applied in blocks, using a stencil, block printing or screen printing [technique] ... the role of this porous pumice-containing layer might have been to absorb some of the oil, so that the paint would be 'touch dry' more quickly, allowing an adjacent block of color to be applied without smudging." 67 Wallpaper-like in its texture, this unusual facture is visible in Booth's rendering of Winter's central figure: the seated gent in an azure coat who gazes cockily out from the picture plane as a servant affixes his ice skates. Guided by his twin thickly outlined, gloved index fingers as they gesture down to the russet ground, we can see a tan margin flanking three sides of his chair-leg. Contrary to the logic of the picture's fiction, this ground reads up through the umber hue of the servant's cast shadow. Like the tree trunk rising up as a tracery of pale-white and blue-grey arabesques from the dun-colored snow, these blocky forms appear to have been stamped out on, and not brushed onto, prepared canvas.

However it was achieved, this chymo-mechanical process was advertised as immune to the vulnerabilities besetting the high-status objects it replicated. Pollaplasiasmos was impervious, Booth claimed, "to changing, cracking, peeling, or another other of those inconveniencies, which frequently attend first rate pictures painted in the usual way: so that it will multiply pictures in such a manner as to perpetuate the genius, style, and effect of the most celebrated painters, to the most distant ages." 68 More important still to Reynolds's polychrome

perpetuation, though, were his transactions with enamelists including Henry Bone (1755-1834) and William Russell Birch (1755-1834).69 Trained at porcelain works in Reynolds's native Devonshire, Bone began exhibiting at the Royal Academy in 1781 where he showed reproductions of oil paintings in his laborious enameling technique. Demonstrated by the remarkable preparatory study of Reynolds's self-portrait in academic robes (fig. 10) now in the collection of the National Portrait Gallery, London, Bone prepared crisp graphic renderings of the portrait he was to translate into enamel on gridded, numbered sheets. He then applied pigmented metal oxide powders suspended in vegetal oils onto coated metal supports, which were fired at upwards of eight hundred degrees Fahrenheit.70 Unlike oil painting where pigments could easily be mixed, revised, and otherwise improvised, each chromatic layer of an enamel painting had to be fired
9 Joseph Booth, "Polygraph" print after Philippe Jacques de Philippe Jacques de Lour 780-1790. Mechanica oil painting on canvas, $34 \frac{3 / 4}{4} \times 49$ in. $(88.3 \times$ 124.2 $\mathrm{cm}$ ). The British Museum, London, 1982 0619.2 independently and in sequence such that the color with the highest melting point was fired first. Bone's reproductive transpositions were further enhanced by the innovative, glossy "flux" he added as a prophylactic fixing layer. ${ }^{71}$ Made brilliant and durable by these repeated firing processes, Bone's enamels were recognized by contemporaries as the persisting standard through which subsequent generations could know Reynolds's excellence as a pictorial colorist. J. T. Smith put the point this way: "As much as of the interest of Sir Joshua's pictures is annually lessened by the fading of his colours, the surest means of handing down to posterity that great Artist's fascinating style of colouring, [are] the correct copies which Mr. Bone has made of them in enamel." 72

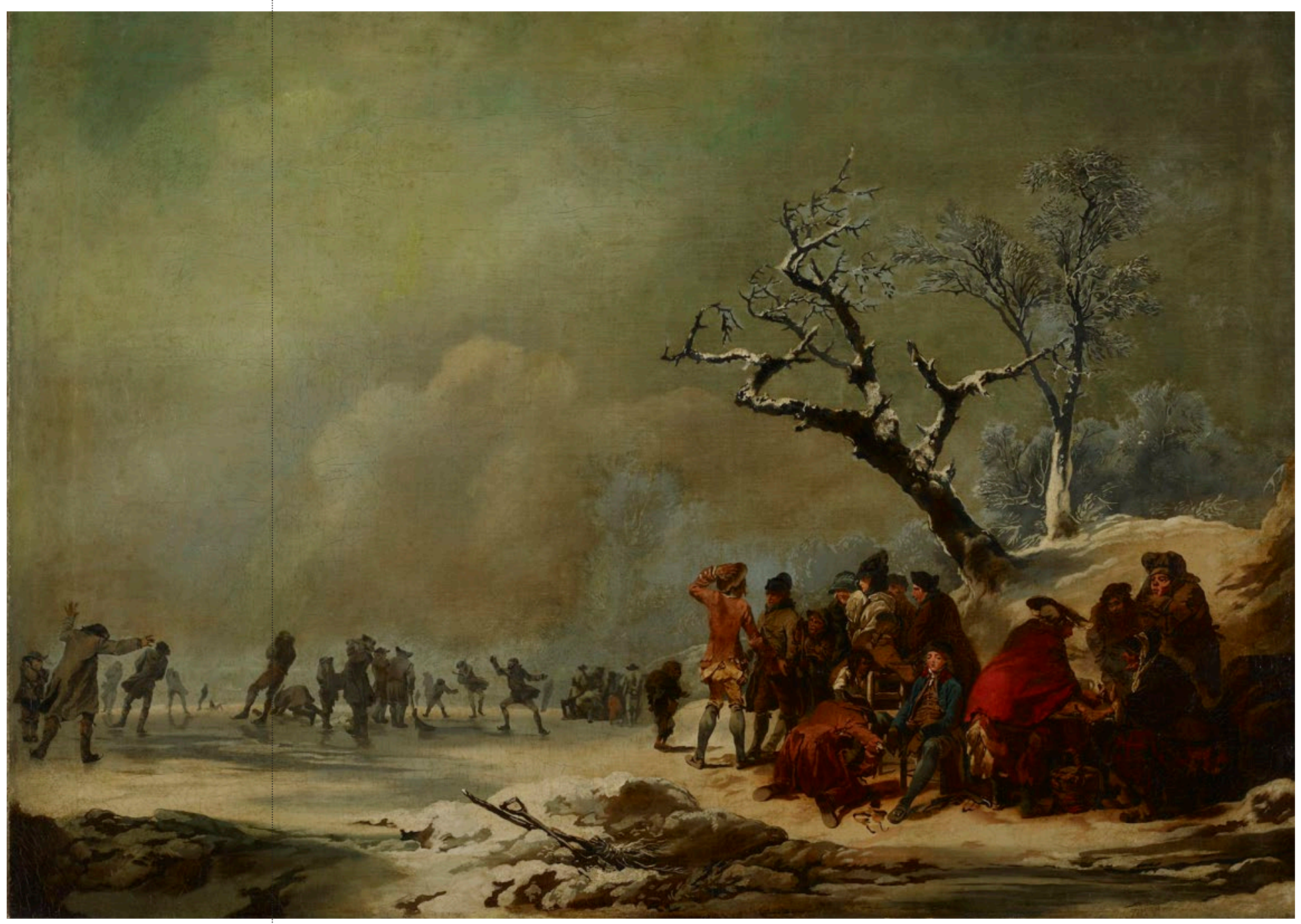


Henry Bone, Study of Sir Joshua Reynolds, April 1804 (ca. 1780). Pencil drawing squared in ink for transfer, $10 \times$

$7 \%$ in. $(25.3 \times 19.5 \mathrm{~cm})$ National Portrait Gallery London, NPG D17345

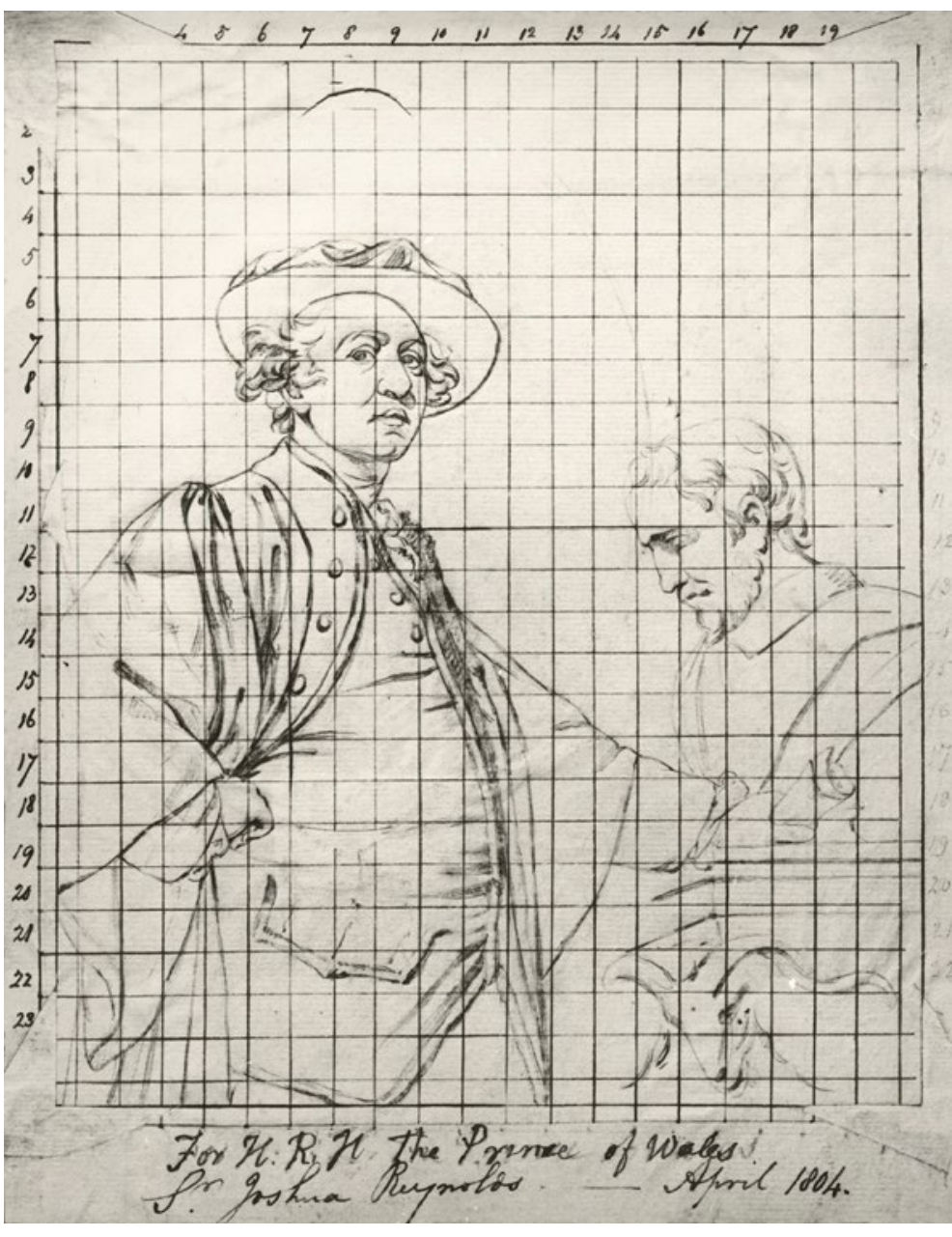

Designed to maintain Reynolds's fugitive, florid forms, the enamelist's techniques of chymical preservation were trucked across the Atlantic by William Russell Birch. Arriving in Philadelphia in 1794 bearing a letter of introduction from Benjamin West, Birch met with checkered success in the early United States where he acted as painter printer, landscape architect, and frustrated advocate for the fine arts. ${ }^{73}$ As outlined in his Life and Anecdotes of William Russell Birch, Enamel Painter (ca. 1815-1834), enamel was a "chymical practice" ideally

suited for pictorial conservation. ${ }^{74}$ It is "the Unique art of hightening and preserving the beauty of tints to futurity, as given in the Works of the most celebrated Masters of Painting, without a possibility of there changing." 75 Birch went on to explain to an American readership how his own technical innovations with "calcined Terrovert compounded with the soft well-melted Fluxes from crucibles of the imitative Jewellers' manufactory" enabled him not only to achieve an innovative, brown enamel hue that could simulate Reynolds's rich palette, but how doing so had won him a medal in 1784 from London's Society for the Encouragement of Arts, Manufactures and Commerce. ${ }^{76}$ Chymically improved, enamel painting figured among the strategies for sustaining the much-bemoaned fragility of life for artists and art objects alike in the early United States.

If less systematic than the experimental enamel panels produced in contemporaneous collaboration between George Stubbs and Josiah Wedgwood, Reynolds's own palette was seen by contemporaries as reciprocally engaged with the materials of his enamelist replicators. ${ }^{77}$ Poet William Mason describes how the Royal Academy president's preferred blue smalt pigment was "a highly vitrified substance, that the art of enamelling, and that of making china” had improved industrially to the point of rivaling those found in Asian export porcelain. ${ }^{78}$ Thus, whether printed in chymo-mechanical multiples by Booth or fired at blistering temperatures by enamelists like Bone and Birch, Reynolds both encouraged and integrated materials of production from a complex array of reproductive artists able to make durable, chymical pictures from his destabilizing painted things. Yet given the ways in which they pursued the president and vied for rights to reproduce his works, it might be better to say that these chymical practitioners "courted" Reynolds. ${ }^{79}$ Courtly models are indeed instructive here. In a perceptive analysis of science at the absolutist court, Mario Biagioli outlines a crucial asymmetry between the high-status patron and aspiring clients. Where such ambitious clients stood to gain much from princely patrons through audacious challenges to their intellectual rivals, those patrons had to take care to position themselves at safe distance from the acrimonious fray. "Great patrons," Biagioli observes, "were as vulnerable as they were powerful. . . . To be powerful meant being fragile, and to be fragile meant being powerful." 80 Tricky as were Reynolds's own relations to George III, court culture's lessons for Britain's leading, knighted painter were clear enough. While Walter Benjamin saw the withering of art's aura in the age of technologized, lithographic reproducibility, Reynolds's entourage of chymical picture makers suggests a different model of artistic power-one where the fragile, chymically unstable masterpiece is surrounded by kindred clients competing for its visibility and propagation.

The acute asymmetries between those fugitive, vulnerable alloys struck by the fabulously wealthy "father of the English School of 
Painting" and the enduring work of his pictorial technicians, however, also bred bad feelings. ${ }^{81}$ Consider again Hone's Pictorial Conjuror (see fig. 3). In light of J. T. Smith's claim that Hone was "a fashionable Miniature-painter in enamel” frustrated by Reynolds's stranglehold on the art market, Pictorial Conjuror can be read as a pointed critique not only of the president's undue influence on impressionable youth like the child folded into the conjuror's lap but also of the paint-to-picture transit outlined here.82 Rather than the enamelist's purifying fire that could render pictures durably brilliant, Hone shows a charlatan's false flame - the "pale fire" that Shakespeare's arrant thief, the moon, snatches from the true, sun-like artist. ${ }^{83}$ Equally, Hone is the Morning Chronicle's Socratic gadfly. If classical language could secure artistic timelessness from staining matter for the Morning Chronicle writer,

Hone visualizes robust resistance from the perspective of the modern, chymical practitioners required to accomplish those paintings' material perpetuation. Picturing, in this view, is a trick, and Reynolds is an alchemical trickster.

\section{Chance, Taken and Tamed}

In his influential Handmaid to the Arts (1764), London-based chymist Robert Dossie had pledged that "a deeper knowledge of the principles and practice of chymistry is requisite" to advancing the enamel painter's practice. ${ }^{84}$ Arriving in the early United States at what one recent historian has called "a time of risk, not fixity, when great personal fortunes could be made and lost," William Russell Birch expressed little more confidence in the epistemological foundations of his enamel enterprise. ${ }^{85}$ Since enamel painting awaited any standardization of its pigments and required so much delicacy in a master's hand to yield its brilliant hues, Birch concluded: "There is no regular scientific principles laid down for this Art, its practice has hitherto depended upon chance." 86 Yet as much as any artist could do, Birch may have come to Philadelphia in the 1790 exceptionally well prepared for taking precaution against chance's vagaries. Economic historian Jonathan Levy has recently traced a compelling history of freedom under nineteenth-century American capitalism as the terrestrial landing of "risk" from an oceanic world of commodities "Born on the deep, in the act of maritime voyaging," as Levy puts it, risk was not some amorphous fear of the unknown: "Rather, it referred to something material: a financial instrument for coping with the mere possibility of peril, hazard, or danger." 87 In his autobiography, Birch foregrounds his close relationship with and patronage by William
Murray (1705-1793), first Earl of Mansfield, a leading jurist of maritime law and one of the major Anglo-American architects of risk's legal grounding. ${ }^{88} \mathrm{~A}$ staunch defender of predictability and certainty in mercantile legislation, Mansfield had doubts about Joshua Reynolds. Birch claimed that only at his prompting did Mansfield finally sit for Reynolds in 1785 , having rebuffed the painter for a decade. 89

Now, whether or not Mansfield's hesitation stemmed from the gamble he knew himself to be taking when commissioning a portrait from the Royal Academy president-a painter who grew up near the major port of Plymouth, who built a crucial client base around Britain's naval officer class-Reynolds seems to have apprehended risk's broad principles. As with the legal doctrine of insurable interest whereby "a merchant could only insure property in which he had a pecuniary "interest," Reynolds recognized that he too should limit his chymical experiments to speculatively produced exhibition works, rather than those painted on commission. ${ }^{90}$ Northcote tells us that the president had hoped to confine his "experiments ... [to] his fancy pictures, and if so, had they failed of success, the injury would have fallen only on himself." 91 If Jennifer Roberts has taught us to see oceanic transit embodied in Copley's Pelham portrait, might we not equally find the watery world of maritime risk imported into Birch's transatlantic collaboration with Reynolds as so much pictorial insurance bought against the chance of paint's chymical decay?

However we answer this question, Birch, Hone, and their contemporaries would have confronted a bold meditation on the central role of chymical chance to grand manner art in Reynolds's own publicly delivered discourses. Read less than six months before Hone's Pictorial Conjuror was exhibited, Reynolds's "Discourse vi" foregrounded relations among the artist, fire, and what might be called the felix culpa of chymical transformation. In stated aim, "Discourse vi" sought to defend a project of emulative imitation rooted in the works of classical antiquity and the Old Masters - to beat back a rising Romantic tide that would place private cerebration of untutored genius as the necessary and sufficient condition for artistic invention. Contesting the tendency of "those who are unacquainted with the cause of any thing extraordinary, to be astonished at the effect, and to consider it as a kind of magick," Reynolds's lecture outlines a method by which the studious artist can gather then carefully mix elements from a wide-ranging canon to make new art.92 As he puts it: "The fire of the artist's own genius operating upon these materials which have been thus diligently collected will enable him to make new 
11

William Hogarth, Time Smoking a Picture, ca. 1761. Etching, engraving, and mezzotint, $10^{3 / 8} \times$ $7^{1 / 4} \mathrm{in} .(26.2 \times 18.4 \mathrm{~cm})$ The British Museum, London, $\mathrm{Cc}, 1.167$

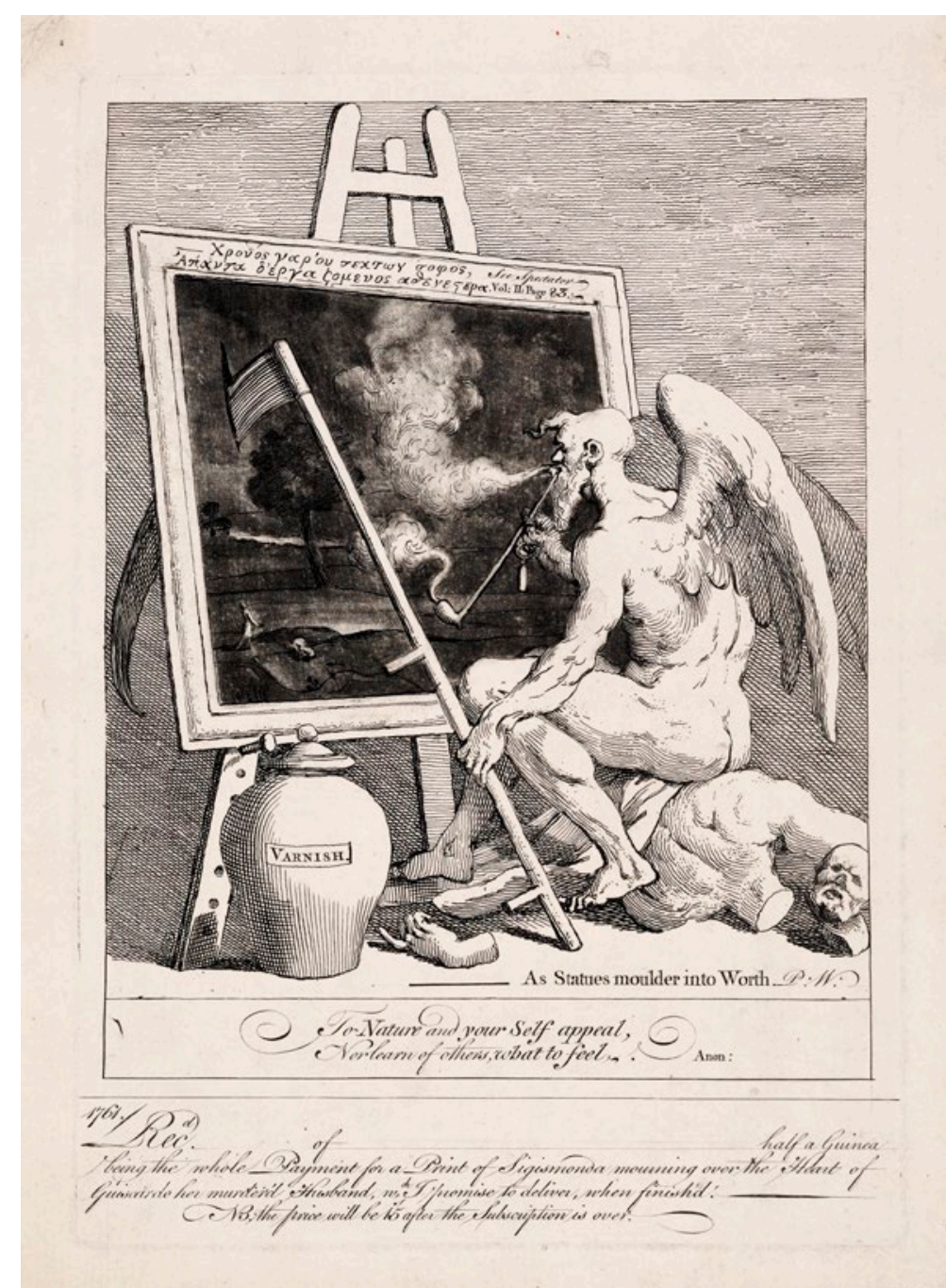

combinations, perhaps, superior to what had ever before been in the possession of the art." 93 But the president then takes that combustible fire back to its metallurgical roots within a longer chymical tradition. The artist "will pick up from dunghills what by a nice chymistry, passing through his own mind, shall be converted into pure gold; and, under the rudeness of Gothick essays, he will find original, rational, and even sublime inventions." 94 Art is Art, in this view, because its innovative, dazzling effects are nonetheless grounded in a capacious command of the past bent to intended causes, inaccessible and mystified though those may appear to an ignorant public.

Yet as Joseph Wright had then recently done when dramatizing the chance discovery of artificial phosphorous in his The Alchymist, in Search of the Philosopher's Stone, Discovers Phosphorous, and prays for the Successful Conclusion of his operation, as was the custom of the Ancient Chymical Astrologers (first shown in London in 1771), Reynolds also models invention as accident in "Discourse vi." The creation of artistic novelty from a serried, pictorial assemblage of past exemplars unfolds through serendipity, a term itself coined by Horace Walpole in 1745 "to describe the making of unexpected yet insightful discoveries "by accident and sagacity." 95 By this second view, innovation occurs "as in the mixture of the variety of metals, which are said to have been melted and run together at the burning of Corinth [in $146 \mathrm{BC}$ ], a new and till then unknown metal was produced, equal in value to any of those that had contributed to its composition." 96 Simultaneously,

then, artistic innovation is both an intentional, teachable science guided by trained, mental "chymistry" toward the production of lasting value; and it is a felicitous accident occurring as the artist collaborates with and profits from unexpected chymical events as at ancient Corinth. 97

When thus asking whether Reynolds painted his pictures, we need to recall how capacious the president's own works became for imagining felicitous, visual interventions from nonhuman collaborators. The architect should, so the president counseled in his

"Discourse XIII" of 1786, "take advantage sometimes of that to which I am sure the Painter ought always to have his eyes open, I mean the use of accidents; to follow when they lead, and to improve them, rather than always to trust to a regular plan." 98 As told by Northcote, being open to the happy hand of chance was a working precept in the president's studio. Reynolds instructed his apprentice to always have two similar canvases on the go in the studio, so that "if chance produced a lucky hit, then instead of working upon the same piece, and perhaps by that means destroy the beauty which chance had given," it could simply be transferred onto the other picture. ${ }^{99}$ Nor was chance the only nonhuman force to which a painter should avail himself.

Northcote recounts a tale of an old woman who "remembered, that, at the time when she sat to Vandyke, for her portrait, and saw his pictures in his gallery, they appeared to have a white and raw look, in comparison with the mellow and rich hue we now see in them, and which time alone must have given to them, adding much to their excellence." 100 The apprentice avowed a similar disappointment on his own first view of Reynolds's pictures fresh off the easel. He was repulsed by what he called "the sight of the raw, crude, fresh appearance of his new 
pictures, which ... seemed to me by no means equal to those I had before seen and so much admired."1o1 Northcote was hardly alone in embracing this aesthetic of patina, this preference for the darkening of artifacts caused by temporal oxidation. That taste was brilliantly satirized by William Hogarth who anthropomorphizes chymical process as Father Time blowing an inky, discoloring cloud of smoke onto a recently finished painting (fig. 11). ${ }^{102}$ Instructively, it was just this collaboration between Reynolds and Time that enamelist Birch sought to perpetuate in his pictures. Birch reports that one of his finest achievements came through applying "a thin layer of yellow Enamel under the last coat of white, ... [which] affects the beauty of Age seen in many of the old paintings in oil by the former masters." 103

Asking the question "Did Joshua Reynolds paint his pictures?" thus opens onto a broader reexamination of the parameters of human intervention in Anglo-American pictorial process at the close of the eighteenth century. Even without enlisting familiar problems at materialist and idealist extremes - the sophisticated distribution of labor among assistants in a busy portrait painter's workshop or, say, claims for the necessity of nature, acting through the artist in the form of genius, for the creation of fine art-we are disabused by Reynolds and his contemporaries of any easy account of just what the painter did, when those actions were completed, and how their material residues would comport themselves to "pictures." 104 While staging the painter's "nice chymistry" as a rational, intentional business, "Discourse vi" simultaneously imagined a nonhuman agency of serendipitous chymical transformation at the heart of artistic invention. Like Aaron in his infamous account of the golden calf's yield ("I cast gold into the fire, and there came out this calf” [Exodus 32:24 (KJV)]), the president had explained image making as metallic transmutation by fire over which the artist's control was, if not indifferent, at least never total. 105 Reciprocally, as Northcote and others show, such chanced and chancy effects were not only desirably visible in Reynolds's works but veritably taught in his studio. Effectively, then, Reynolds had set up terms whereby neither he nor anyone else could be said to have painted his pictures exclusively. That is, whether or not "picture" adequately denotes their results, the painter's actions were necessarily collaborations theorized to, and valued for, changing chymically in time. From adepts in the secrets of what James Barry scornfully called "magilphs and mysteries" such as West and Allston to technical experimentalists as audacious as William Page ("America' Reynolds") and Ryder, the cornerstones of painting in the emergent
American tradition cannot be seen apart from that volatile, Reynoldsian dynamic. 106

Attending to that legacy also forces us back into the present. At the heart of an influential essay, literary critic Walter Benn Michaels analyzes a scene from Edith Wharton's The House of Mirth (1905) where protagonist Lily Bart reenacts a posture borrowed from none other than Joshua Reynolds. A charged, trembling play between intention and chance, action and accident, Lily Bart's tableau vivant performance as Reynolds's Mrs. Lloyd (1775-1776) exemplifies what Michaels calls "a certain moment in the appeal of indeterminacy," which he traces through chance operations, writing, and thinking about photography at the turn of the twentieth century. ${ }^{107}$ Michaels's note of this passage from Wharton is suggestive given the growing role Reynolds has begun to play in histories of photography in the long nineteenth century. ${ }^{108}$ But the question of pictorial ontology forced by Reynolds's unstable painted objects also offers a pathway toward rethinking propositions central to Michaels's account of painting and photography that figure crucially in broader theoretical debate.

Namely, in a recent essay, Michaels has positioned painting as both a spent historical force and a fundamental other to photography.

Invoking the vicissitudes of those shaped canvases interpreted by Fried in the 1960 s (see fig. 4), he writes: "There is an important sense ... in which the question about the [modernist] painting - is it a painting or an object? - has become the question about the photograph." 109 Is it a picture or an index? Is a photograph a representation made intentionally by an artist, or is it a replication caused in some way by the world? Photography's vitality to contemporary art and even its ability to sustain the possibility of art as such derive, Michaels claims, from its precarious extension of determinations that painting by its nature settles simply and unequivocally. Where objects are "causally indispensable" to photography's ways of picturing, painting is not so constrained. By Michaels's reading: "No one doubts the relevance of the portrait painter's intentionality to the portrait-everything on that canvas has been put there by him." 110

Reynolds, Northcote, and their contemporaries disabuse us, however, of the confidence with which we can avow this view of painting in historical terms. Whatever may have been the local intentions of the long eighteenth century's leading portrait painter in the Anglo-American tradition, the Reynoldsian Pictor could see himself as - was understood to be, and was valued for-enlisting the agency of nonhuman forces not entirely under his control so as to yield 
12

Photograph of Henry E. Huntington's Painting of Lavinia, Countess Spencer, late 1920 s.

The Huntington Library,

Art Collections,

and Botanical Gardens,

San Marino, CA

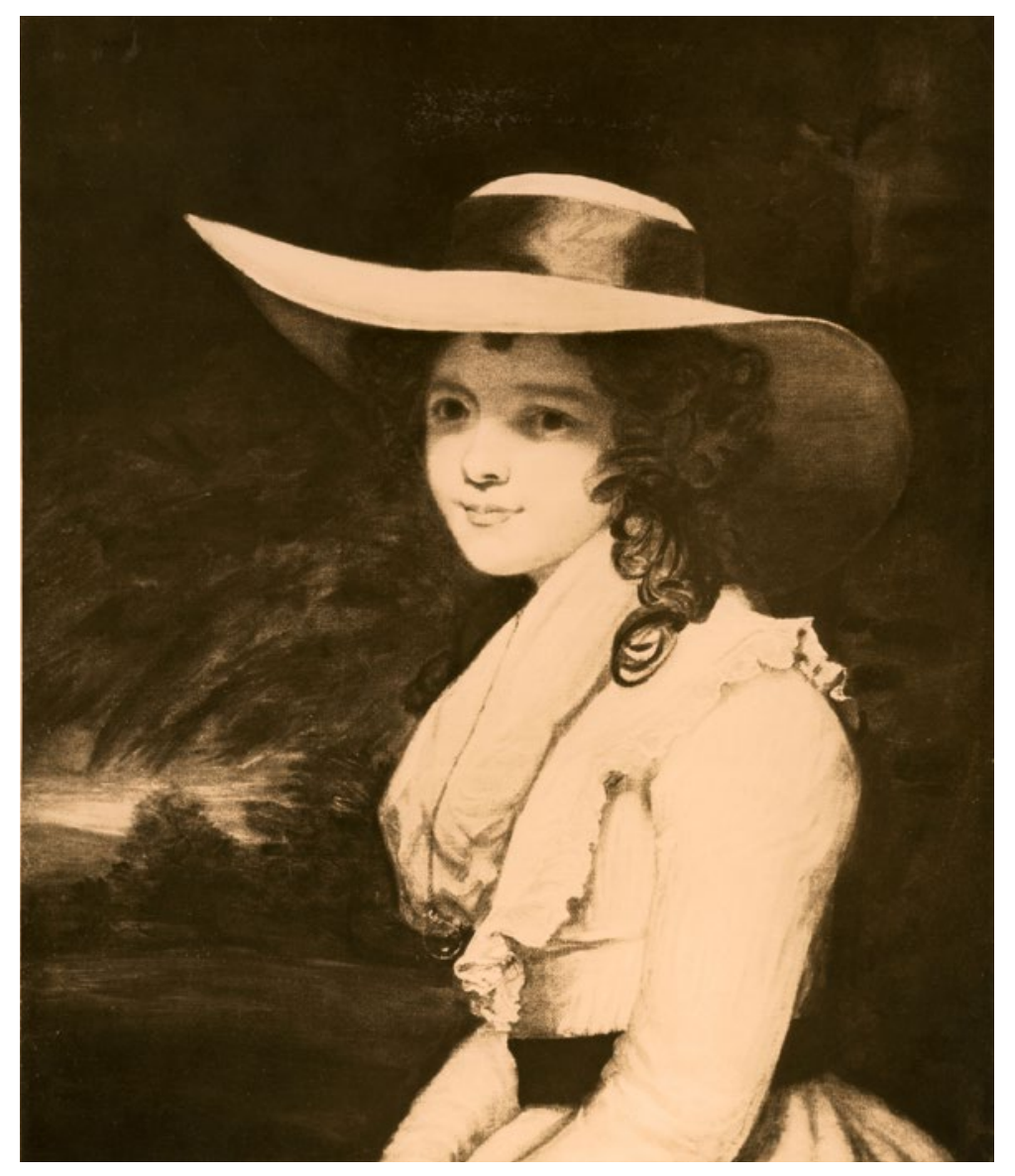

desirable effects, which would only become visible in time. If, as the testimony of Booth, Bone, Birch, and Hone makes clear, those temporally evolving chymical objects called "paintings" needed to both age and yet somehow also persist into the future as "pictures," then the Pictor's intentionality might well be seen as no less complicated than Michaels would have it be in photography. Indeed, in light of the unusual chymical experiments introduced into Anglo-American practice in Reynolds's paintings and their reciprocal relations to the innovative strategies of chymical replication by which they were disseminated, historians of Anglo-American art and theorists of photography alike would do well to extend the complex network of action and accident implicating the photograph to painting as well. Rather than purporting an ontological rupture between them, we might instead plot painting and photography, along with pollaplasiasmos, lithography, enameling, aquatint, and other techniques as so many moves within a broader Enlightenment tradition of working and thinking with temporally evolving chymical objects - a tradition in which what we now call photography is but one sequence of iterations, not a teleological culmination.

Two such chymical images and one final address to my titular question can make the advantages of this approach clearer. In the 1920s, English scholar C. H. Collins Baker was commissioned to catalogue the British art collection of Henry E. Huntington in southern California."11 There, he became embroiled in an acrimonious dispute, then lawsuit, over the authenticity of a depiction of Lavinia sold by Countess Spencer to Huntington as a Reynolds by the Duveen Brothers. 112 Collins Baker did not believe a word of it. On the back of a photograph (fig. 12) now in the Huntington's conservation files, he wrote: "The Huntington version is a copy by a painter to whom the essence of Reynolds was unperceived. In the autograph version at Althorp, the hair has a silvery bloom. The arabesque or festoon of the lace edge of the cape is a lovely example of Reynolds's fluid calligraphic rhythm: rippling up and over the shoulder without a break in the flow." 113 Collins Baker might well have remembered the lessons that the tradition of West, Allston, and others had brought back to the United States from Reynolds's ambit. For Collins Baker's connoisseurial judgments were overturned when period letters proved that Reynolds had produced multiple versions of the picture for the Spencer family. In a nod to the slipperiness of Reynolds's liquid intelligence, a colleague subsequently forwarded to Collins Baker a chymical image then some thirty years old: a lithographed newspaper headline from the New York Times aligning Reynolds with pictorial piracy (see fig. 2). ${ }^{114}$ Did Joshua Reynolds paint his pictures? In this light, yes; and he did so many times over. 
For this series, see Anthony Blunt, The Paintings of Nicolas Poussin: A Critical Catalogue (London: Phaidon, 1966), 73-76. For the king's visit, see William T. Whitley, Artists and Their Friends in England, 1700-1799 (Boston: Medici Society, 1928), 2:75-78. On exhibitions at Somerset House more broadly, see D. Solkin, ed., Art on the Line: The Royal Academy Exhibitions at Somerset House, 1780-1836 (New Haven, CT: Yale University Press, 2002).

2 For more on Byres and his art dealing, see Paolo Coen, "Andrea Casali and James Byres: The Mutua Perception of the Roman and British Art Markets in the Eighteenth Century," Journal for Eighteenth-Century Studies 34, 3 (2011): 291-313; and John Ingamells, $A$ Dictionary of British and Irish Travellers in Italy, 1701-1800 (New Haven, CT: Yale University Press, 1997), 169-72. For the Fitzwilliam Museum's fund-raising efforts, see "Fitzwilliam Succeeds in Saving Poussin Masterpiece for the Nation," Nov. 2, 2012, accessed Dec. 3, 2013, http://www.cam.ac.uk/news/fitzwilliam-succeeds-in-saving-poussin-masterpiece-for-the-nation.

3 See Brian Fothergill, Sir William Hamilton: Envoy Extraordinary (London: Faber and Faber, 1969), 192-93.

4 Joshua Reynolds to Charles, 4 th Duke of Rutland, Oct. 4, 1786, in The Letters of Sir Joshu Reynolds, ed. .). Ingamells and ). Edgcumbe (New Haven, CT: Yale University Press, 2000), 173

5 Joshua Reynolds to Charles, 4th Duke of Rutland, July 5, 1785, in Letters of Sir Joshua Reynolds. 142. See Theodore Vrettos, The Elgin Affair: The Abduction of Antiquity's Greatest Treasures and the Passions It Aroused (New York: Arcade, 1997).

6 This image is likely not a pure lithograph but printed on top of copper etching; I thank Geoffrey Belknap for advising me on this point.

$7 \quad$ "Sir Joshua Reynolds Helped to Pirate Old Masters," New York Times Sunday Magazine, Feb. 1, 1914, 1. For more on one possible prompt to this editorial, the Special Loan Exhibition of Old Masters of the British School, which opened at the Duveen Brothers gallery in New York in January 1914 and prominently featured work by Reynolds, see Elizabeth A. Pergam, "Provenance as Pedigree: The Marketing of British Portraits in Cilded Are America" in An Alternative History of Art, ed. G. Feigenbam and $I$.
Reist (Los Angeles: Getty Research Institute, 2012), 04-22. On the Old Master market and its players more broadly, see Flaminia Gennari Santori, The

Melancholy of Masterpieces: Old Master Paintings in America, 1900-1914 (Milan: 5 Continents, 2003): and John Brewer, The American Leonardo: A Tale of Obsession, Art and Money (Oxford: Oxford University Press, 2009).

8 Recent technical studies also indicate that Reynolds was not immune to repainting Old Master pictures in his collection, including works by Rembrandt; see Henri Neuendorf, "X-Ray Analysis Reveals Joshua Reynolds Repainted Rembrandt Masterpiece," Artnet, Mar. 5, 2015, accessed May 27 2015, https://news.artnet.com/

n-brief/x-ray-analysis-reveals-joshua-reynolds-repainted-rembrandt-masterpiece-273509.

9 Edmond Malone, "Some Account of the Life and Writings of Sir loshua Reynolds" in The Literary Works of Sir Joshua Reynolds, 5 th ed., ed. Edmond Malone (London: T. Cadell \&W. Davies, 1819), 1:xli-ii.

\section{See ibid., 1:xlii-xlv}

11 Joshua Reynolds, "Discourse VI," in Discourses on Art, ed. R. W. Wark (New Haven, CT: Yale University Press, 1997), 107

2 For more on this picture, see John Newman, "Reynolds and Hone: 'The Conjuror' Unmasked," in Reynolds, ed. N. Penny (London: Royal Academy, 1986), 344-54; and Konstantinos Stefanis, "Nathaniel Hone's 1775 Exhibition: The First Single-Artist Retrospective," Visual Culture in Britain 14, 2 (2013): $131-53$

3 See Horace Walpole, Anecdotes of Painting in England ... (Strawberry-Hill: Thomas Kirgate, 1771), 4:vil.

14 Joseph Farington, "Memoirs of the Life of Sir Joshua Reynolds with Observations on His Talents and Character," in Malone, Literary Works of Sir Joshua Reynolds, 1:ccxii

\section{I will subsequently abbreviate this title as} Morning Chronicle.

16 "For the Morning Chronicle. To Sir Joshua Reynolds," Morning Chronicle and London Advertiser,
May 11, 1773, n.p.

17 An interesting analogy might be drawn betwee this uncomfortable bleeding of image and pigments and contemporaneous confusions between painters media and the makeup worn by their sitters; see Aimee Marcereau Degalan, "Dangerous Beauty: Painted Canvases and Painted Faces in Eighteenth-Century Britain" (PhD diss., Case Western Reserve University, 2007), esp. 124-26.

18 "To Sir Joshua Reynolds," n.p.

19 On the extent of the war's importance to art in Britain, see Douglas Fordham, British Art and the Seven Years' War: Allegiance and Autonomy (Philadelphia: University of Pennsylvania Press, 2010).

20 Although they are beyond the scope of this essay, precepts drawn from Mediterranean antiquity and the ealy Christion cult of images might be seen subtend this conversat would be Plato's distinction, as noted later in the essay, between an archetypal, immaterial idea (eidos) and its redundant replication by art (mimesis techne), as well as the differentiation forged in the era of Byzantine iconoclasm between the legitimate honor given to an archetype through reverence to a material image (proskynesis) and what would be translated by Carolingian observers of that Greek debate as the mistaken worship of the material image itself (adoratio). For general overviews of these traditions, see Erwin Panofsky, Idea: A Concept in Art Theory (Columbia: University of South Carolina Press, 1968); Hans Belting Likeness and Presence. A History of the Image before the Era of Art, trans. E. Jephcott (Chicago: University of Chicago Press, 1994), esp. 144-63, 503-5, 533-35; and David Freedberg, The Power of Images: Studies in the History and Theory of Response (Chicago: University of Chicago Press, 1989), esp. 392-405.

21 James Elkins, The Domain of Images (Ithaca, NY Cornell University Press, 1999), 55. For critiques of the ways in which academic art history has privileged two-dimensional "pictures" exemplified par excellence by post-Renaissance easel painting, see Michael Yonan, "Toward a Fusion of Art History and Material Culture Studies," West 86th 18, 2 (2011): 232-48.

22 Michael Fried, "Shape as Form: Frank Stella's Irregular Polygons," in Art and Objecthood: Essays and
Reviews (Chicago: University of Chicago Press, 1998), 95. For Stella's own apposite thoughts (albeit from two decades later) on the antagonism between "pictoriality" and materiality, see Frank Stella, Working Space: The Charles Eliot Norton Lectures, 1983-84 (Cambridge MA: Harvard University Press, 1986), esp. 71-98.

23 On the breadth and complexity of Goodman's engagement with modern art, see Curtis L. Carter "Hockey Seen: Nelson Goodman," in Hockey Seen: A Nightmare in Three Periods and Sudden Death: A Tribute to Nelson Goodman (Milwaukee, WI: Haggerty Museum of Art, Marquette University, Sept. 28 2006-Jan. 14, 2007), n.p.

24 Nelson Goodman, Languages of Art: An Approach to a Theory of Symbols (1968; repr., New York: Hackett, 1976), 229.

25 Jennifer L. Roberts, "Copley's Cargo: Boy with Squirrel and the Dilemma of Transit," American Art 21, 2 (2007): 22 .

26 Ibid., 22-23.

27 A fuller inquiry into the relations between the projects of Fried and Roberts is beyond the scope of this essay But noteshould be made here between Fried's proposal (articulated in 1987) that his accoun of Thomas Eakins found its most important preceden in the "American portraits of John Singleton Copley, many of which also contain striking images of reflections," and the centrality of reflective surfaces to Roberts's recent interpretation of Copley's portraits. Compare Michael Fried, Realism, Writing Disfiguration: On Thomas Eakins fion: OnThos Enicago: University of Chicago Press, 1987), 177n75; and Jennife L. Roberts, Transporting Visions: The Movement of Images in Early America (Berkeley: University of California Press, 2014), esp. 34-49 (see also pp. 7, 169-7on19).

28 See Michael Fried, Absorption and Theatricality: Painting and Beholder in the Age of Diderot (Los Angeles: University of California Press, 1980).

29 For this quote, see Robert Smithson, "Letter to the Editor," in Robert Smithson: The Collected Writings, ed. J. Flam (Los Angeles: University of California Press, 1996), 67. See Jennifer L. Roberts, Mirror-Travels: Robert Smithson and History (New Haven, CT: Yale University Press, 2004), esp. 33-34; and Robert Linsley, 
"Mirror Travel in the Yucatan: Robert Smithson, Michael Fried, and the New Critical Drama," RES Anthropology and Aesthetics (2000): 7-30. For more on the stakes shared between Fried and Smithson, see Walter Benn Michaels, The Shape of the Signifier: 1967 to the End of History (Princeton, N): Princeton University Press, 2004), esp. 82-128.

30 I owe this astute comparison to David H. Solkin, in conversation with Shelley Bennett; see Shelley Bennett's notes from conversation with Solkin from April 1, 1996, in the Huntington Art Callery object file HEH 23.13 .

31 Louis Simond, Journal of a Tour and Residence in Great Britain during the Years 1810 and 1811 , 2nd ed. (Edinburgh: J. Ballantyne, 1817), 1:49.

32 William Mason, "Anecdotes of Sir Joshua Reynolds, Chiefly Relating to His Manner of Coloring. By W. Mason, the Poet," in Sir Joshua Reynolds' Notes and Observations on Pictures, ed. W. Cotton (London: J. R. Smith, 1859), 54

33 [William Combe], A Poetical Epistle to Sir Joshua Reynolds, Knt. (London: Fielding and Walker, 1777), 5 .

34 Mansfield Kirby Talley, "All Good Pictures Crack': Sir Joshua Reynolds's Practice and Studio," in Penny, Reynolds, 55

35 Neil Harris, The Artist in American Society: The Formative Years, 1790-1860 (New York: George Braziller, 1966), 11. For a recent approach to Anglo-American art that informs my view, see David Peters Corbett and Sa Peters Corbertand Sarah Monks, Anglo-American: Artistic Exchange beween Britain and the USA (Chichester, West Sussex, UK: John Wiley E Sons, 2012)

36 On this American tradition, see Lance Mayer and Gay Myers, American Painters on Technique. The Colonial Period to 1860 (Los Angeles.). Paul Getty American Painters on Technique: 1860-1945 (Los American Painters on Technique: 1860-1945 (Los Angeles: J. Paul Getty Museum, 2013); Joyce Hill Ston Three Nineteenth Century Artists: Allston, Whistler and Ryder," in Appearance, Opinion, Change: Evaluating the Look of Paintings (London: United Kingdom Institute for Conservation, 1990), 36-41; and
David Bjelajac, Washington Allston, Secret Societies and the Alchemy of Anglo-American Painting (Cambridge: Cambridge University Press, 1997).

37 James Northcote, The Life of Sir loshua Reynolds, 2 vols. (London: Henry Colburn, 1810), 1:237. 38 Samuel Johnson, A Dictionary of the English Language (London: Printed by W. Strahan, for ). and P. Knapton et al., 1755-1776), vol. 2, s.v. "picture.

39 Northcote, The Life of Sir Joshua Reynolds, 1:237. In point of fact, Reynolds did subsequently pain portrait of a brewer (in this case, Samuel Whitbread) on a large copper plate; see David Mannings and Martin Postle, Sir Joshua Reynolds: A Complete Catalogue of His Paintings (New Haven, CT: Yale University Press, 2000), 1:470. I thank Alexandra Gent for very kindly calling this point to my attention.

40 Edgar Peters Bowron, "A Brief History of European Oil Paintings on Copper, 1560-1775," in Copper as Canvas: Two Centuries of Masterpiece Paintings on Copper, 1575-1775, ed. Michael K. Komanecky (New York: Oxford University Press, 1999), 10-11.

41 Rica ones, "Wright of Derby's Techniques of Painting" in Wright of Derby, by Judy Egerton (New York: Metropolitan Museum of Art, 1990), 263-71. On York: Metropolitan Museum of Art, 1990), 263-71. On
these techniques more broadly, see Isabel Horovitz, "The Materials and Techniques of European Paintings on Copper Supports," in Komanecky, Copper as Canvas, 63-92.

42 A Catalogue of the Pictures, Sculptures, Models, Designs in Architecture, Drawings, Prints, \&c. Exhibited by the Society of Artists of Great Britain ... (London: Printed by Harriot Bunce, printer to the Society, 1773), 3. More broadly, see Elizabeth E. Barke and Alex Kidson, Joseph Wright of Derby in Liverpoo (New Haven, CT: Yale University Press, 2007), 186.

43 Northcote, The Life of Sir /oshua Reynolds, $1: 239$

44 See The Stanford Encyclopedia of Philosophy Summer 2012 Edition, ed. Edward N. Zalta, s.v. "Identity Over Time," by Andre Gallois, accessed Dec. 2, 2013, http://plato stanford edu/archives/sum2012/entries/ identity-time/. See also Alexander Nagel and Christopher S. Wood, Anachronic Renaissance (New
York: Zone Books, 2010), 8-9.

45 Martin Archer Shee, The Commemoration of Reynolds, in Two Parts, with Notes, and Other Poems (London:I Murray 1814) 12-13. For a digital visualizaWhat lane Saw, accessed July 31, 2015, http://www. whatjanesaw.org/rooms.php?location=NRNE.

46 Ibid., 13-14.

47 Michael Baxandall, Painting and Experience in Fifteenth-Century Italy: A Primer in the Social History of Pictorial Style (Oxford: Clarendon Press, 1972), esp. $14-23$.

48 John T. Smith, Nollekens and His Times: A Life of That Celebrated Sculptor and Memoirs of Several Contemporary Artists, from the Time of Roubilliac Hogarth and Reynolds to That of Fuseli, Flaxman and Blake (London: Colburn, 1829), 2:292.

49 Compare Plato, Platonis Opera, ed. J. Burnet (Oxford: Oxford University Press, 1903), 596B-597E; and Plato, The Republic, trans. R. E. Allen (New Haven CT: Yale University Press, 2006), bk. 10, 326-29. For an informative critical reading of this famous passage, se Stephen Halliwell, The Aesthetics of Mimesis: Ancie Texts and Modem Problems (Princeton. Nl: Princeton University Press, 2002), esp. 37-71.

50 For the Greek, see Plato, Platonis Opera, $597 \mathrm{E}$.

51 On this point, see John Barrell, The Political Theory of Painting from Reynolds to Hazlitt: "The Body of the Public" (New Haven, CT: Yale University Press, 1986), 80. More recently, Celina Fox has characterized Reynolds as positing "an opposition between the mind and the hand, between principle and mere practice", Celina Fox, The Arts of Industry in the Age of Enlightenment (New Haven, CT: Yale University Press, 2009), 216. For pedagogy in the early Royal Academy, see Holger Hoock, The King's Artists: The Royal Academy of Arts and the Politics of British Culture, 1760-1840 (Oxford: Clarendon, 2005).

52 Northcote, The Life of Sir Joshua Reynolds, 1:83.

53 Waldron P. Belknap, American Colonial Painting: Materials for a History, ed. C. C. Sellers (Cambridge, MA: Belknap Press of Harvard University Press, 1959),
54 For this claim, see Ellen D'Oench, Copper into Gold: Prints by John Raphael Smith (1752-1812) (New Haven, CT: Yale University Press, 1999), 25.

55 See Philipp André, Specimens of Polyautography: Consisting of Impressions Taken from Origina Drawings Made Purposely for This Work (London Published by P. André and J. Heath, 1803). For a fascinating account of the export of stone used to produce lithographs from Europe to the early United States, see Philip J. Weimerskirch, "Lithographic Stone in America," Printing History 11, 1 (1989): 2-15.

56 Walter Benjamin, "The Work of Art in the Age of Its Technological Reproducibility: Second Version," in The Work of Art in the Age of Its Technological Reproducibility, and Other Writings on Media, ed. Michael W. Jennings, Brigid Doherty, and Thomas Y. Levin, trans. E. lephcott and others (Cambridge, MA: Harvard University Press, 2008), 20.

57 For concise overview of the Chemical Revolution, see William H. Brock, The Fontana History of Chemistry (London: Fontana, 1992), esp. 84-127. More broadly, see Jan Golinski, Science as Public Culture: Chemistry and Enlightenment in Britain, 1760-1820 (New York: Cambridge University Press, Archibald Revolution: A Contribution to Social Technology (London: Batchworth, 1952).

58 Thomas Fisher, "The Process of Polyautographic Printing," Gentleman's Magazine 78, 1 (1808): 194.

59 Michael Twyman, Lithography, 1800-1850: The Techniques of Drawing on Stone in England and France and Their Application in Works of Topography (London: Oxford University Press, 1970), 4.

60 For West's experimental facture, see Mayer and Myers, American Painters on Technique: The Colonial Period to 1860, 11-24; and Mark N. Aronson and Angus Trumble, Benjamin West and the Venetian Secret (New Haven, CT: Yale Center for British Art, 2008). More broadly, see Bjelajac, Washington Allston, esp. 32-65.

61 From this point in the essay onward, I employ the period spelling "chymical" While doing so follows the general contc that of Reynolds, as discussed later in the essay), it also 
employs a strategy devised by recent historians of science that seeks to undermine the opposition of chemistry to its supposedly benighted other, alchemy. If, as William R. Newman and Lawrence Principe have influentially argued, it was only in the Enlightenment that these previously synonymous terms came to designate a hierarchical opposition, they remained significantly fluid-even importantly confused-in Reynolds's ambit; see William R. Newman and Lawrence M. Principe, "Alchemy v. Chemistry: The Etymological Origins of a Historiographic Mistake," Early Science and Medicine 3, 1 (1998): 32-65.

62 Charles Robert Leslie and Tom Taylor, Life and Times of Sir Joshua Reynolds (London: John Murray, 1865), 1:112

63 Compare Joseph Booth, A Treatise Explanatory of the Nature and Properties of Pollaplasiasmos; or, The Original Invention of Multiplying Pictures in Oil Colours ... (London: J. Rozea, 1784); and Joseph Booth, An Address to the Public on the Polygraphic Art (London: J. Walter, 1788[?]), 4

64 See The Polygraphic Society, A Catalogue of Pictures Copied or Multiplied (for Sale) by A Chymical and Mechanical Process; Exhibited with the Capital Originals from which they have been taken, by The Polygraphic Society, at their Rooms, in Pall-Mall, Being their Eight Exhibition: Opened the 4th of April, 1792 (London: A. Grant, 1792), 11.

\section{Booth, An Address, 9}

66 Ibid. For a classic account of eighteenth-century industrial artists' more familiar attempts to reconcile their projects with regnant neoclassical tastes and

values, see Adrian Forty, Objects of Desire: Design and Society since 1750 (New York: Pantheon Books, 1986), esp. 11-41.

67 David Saunders and Antony Griffiths, "Two Mechanical Oil Paintings after de Loutherbourg: History and Technique," in Studying Old Master Paintings: Technology and Practice, ed. M. Spring (London: Archetype, 2011), 191. See also Barbara Fogarty, "Matthew Boulton and Francis Eginton's Mechanical Paintings: Production and Consumption 1777 to 178 (master's thesis, University of Birmingham), 2010.

68 Booth, An Address, 5
69 The frequency with which any given Reynolds painting was reproduced in enamel is an important question, but one beyond the scope of this essay. As but one example: William Murray, first Earl of Mansfield, commissioned replicas by William Russell Birch after oil portraits by Reynolds and Copley between 1786 and 1793. See Julius Bryant, Kenwood: Paintings in the lveagh Bequest (New Haven, CT: Yale University Press, 2003), 260

70 For more on Bone, see Oxford Dictionary of National Biography, s.v. "Bone, Henry (1755-1834)," by R. I. B. Walker, accessed May 16, 2013, http://www. oxforddnb.com/view/article/2836.

71 For Bone's technique, see Sarah Coffin and Bodo Hofstetter, Portrait Miniatures in Enamel (London: Philip Wilson Publishers, 2000), 9-11.

\section{Smith, Nollekens and His Times, 2:292-93.}

73 On Birch and his career, see Emily T. Cooperman and Lea Carson Sherk, William Birch: Picturing the American Scene (Philadelphia: University of Pennsylvania Press, 2011), esp. 66-98; and Therese O'Malley, "Cultivated Lives, Cultivated Spaces: The Scientific Garden in Philadelphia, 1740-1840," in Knowing Nature: Art and Science in Philadelphia, 1740-1840, Yale University Press, 2011), 36-59.

74 William Birch, The Life and Anecdotes of William Russell Birch, Enamel Painter, as reproduced in Cooperman and Sherk, William Birch, 169-70. I thank Emily T. Cooperman for helpful information on the dating of Birch's autobiography.

75 Ibid., 169

76 Ibid., 171.

77 See Bruce Tattersall, Stubbs \& Wedgwood: Unique Alliance between Artist and Potter (London:

\section{Mason, "Anecdotes," 54}

79 For accounts of Reynolds's chymical reproducers insinuating themselves in his favor, compare Birch's account of his relations to this "father of the English School of Painting" and his catalogue of enamels after Reynolds (Birch, in Cooperman and Sherk, William
Birch, 171-78, 242-48) and Booth's claim that a portrait offered in pollaplasiasmic reproduction "was painted by Sir Joshua Reynolds expressly for the Polygraphic Society" (The Polygraphic Society, A Catalogue of Pictures, 9). More broadly, see D'Oench Copper into Gold, 13, 25-27.

80 Mario Biagioli, Galileo Courtier: The Practice of Science in the Culture of Absolutism (Chicago: University of Chicago Press, 1993), 80.

81 Birch, in Cooperman and Sherk, William Birch, 171.

82 See Smith, Nollekens and His Times, 1:133. For an overview of Hone's career, see Adrian Le Harivel, Nathaniel Hone the Elder (Dublin: Town House, in association with the National Gallery of Ireland, 1992).

83 See Vladimir Nabokov, Pale Fire (1962; New York: Vintage International, 1989). On the historical connections between enamel painting and alchemy see Michael Cole, Cellini and the Principles of Sculpture (Cambridge: Cambridge University Press, 2002), 15-42.

84 Robert Dossie, The Handmaid to the Arts (London: Printed for I. Nourse, 1764), 264. See also F. W. Cibbs, "Robert Dossie (1717-1777) and the Society of Arts," Annals of Science 7, 2 (1951): 149-72.

85 Cooperman and Sherk, William Birch, 66

86 Birch, in Cooperman and Sherk, William Birch,

87 Jonathan Levy, Freaks of Fortune: The Emerging World of Capitalism and Risk in America (Cambridge, MA: Harvard University Press, 2012), 3.

88 For his account of his relations with "my late friend and patron the Earl of Mansfield," see Birch, in Cooperman and Sherk, William Birch, 173-87. On Mansfield's importance to the legal foundations of risk see Levy, Freaks of Fortune, 35, 40, 48 .

89 For Mansfield's claim that "the great object in every branch of law, but especially in mercantile law, is certainty," see Oxford Dictionary of National Biography, s.v. "Murray, William, first earl of Mansfield (1705-1793)," by James Oldham, accessed Dec. 28, 2013 http://www.oxforddnb.com/view/article/19655.
90 See Levy, Freaks of Fortune, 34

91 Northcote, The Life of Sir Joshua Reynolds, 2:21.

92 Joshua Reynolds, "Discourse VI", 94. For recent scholarship on early modern attempts to reckon with the production of artistic novelty through emulation, see Richard T. Neer, "Poussin, Titian, and Tradition: The Birth of Bacchus and the Cenealogy of Images," Word E Image 18, 3 (2002): 267-81; and Maria H. Loh, "New and Improved: Repetition as Originality in Italian Baroque Practice and Theory," Art Bulletin 86, 3 (Sept. 2004): 477-504.

\section{Reynolds, "Discourse Vl," 106}

94 Ibid., 107. For an interesting examination of the alchemical traditions informing theories of mind on which Reynolds could be drawing see Antonio Clericuzio, "The Internal Laboratory: The Chemica Reinterpretation of Medical Spirits in England (1650-1680)," in Alchemy and Chemistry in the 16th and 17 th Centuries, ed. P. Rattansi and A. Clericuzio (Boston: Kluwer, 2002), 51-83.

95 Donald Preziosi, Rethinking Art History: Meditations on a Coy Science (New Haven, CT: Yale University Press, 1989), 93

96 For ancient sources and alchemical connections of this mythical story, see David M. Jacobson, "Corinthian Bronze and the Gold of the Alchemists," Gold Bulletin 33, 2 (2000): 60-66.

97 This reciprocal dialogue with artistic and chemical tradition seems to subtend Reynolds's claim in preparatory notes for "Discourse Vl" that "when I recommend ... enriching $\&$ manuring the mind with other mens thoughts I suppose the Artist to know his Art so as to know what to choose and what to reject": cited in Frederick Whiley Hilles, The Literary Career of Sir Joshua Reynolds (Cambridge: Cambridge University Press, 1936), 224

98 Joshua Reynolds, "Discourse XIII," in Discourses on Art, 243

99 Northcote, The Life of Sir Joshua Reynolds, 2:7.

100 Ibid., 2:40. 
102 On patina, see articles by Randolph Starn, Eileen Cleere, and Darcy Grimaldo Grigsby in Representations 78, 1 (Spring 2002): 86-144.

103 Birch, in Cooperman and Sherk, William Birch,

104 For the most recent overview of Reynolds's workshop practices, see S. Smiles, ed., Sir/oshua Reynolds: The Acquisition of Genius (Bristol: Sansom E Company, 2009). For the most influential period meditation on the role of genius in the fine arts, see Immanuel Kant Critique of /udgment [1790], trans. W. Pluhar (Indianapolis, IN: Hackett, 1987), esp. § 46-7.

105 An instructive meditation on this episode is Joel Snyder, "What Happens by Itself in Photography?," in Pursuits of Reason: Essays in Honor of Stanley Cavel, ed. T. Cohen et al. (Lubbock: Texas Tech University Press, 1993), 361-73.

106 See John Gage, "Magilphs and Mysteries," Apollo 8o (July 1964): 38-41. For this labeling of Page, see Mayer and Myers, American Painters on Technique: 1860-1945, 1 .

107 Walter Benn Michaels, "Action and Accident: Photography and Writing," in The Gold Standard and the Logic of Naturalism: American Literature at the Turn of the Century (Los Angeles: University of

California Press, 1987), 239. More recently, see Robin Kelsey, "Of Fish, Birds, Cats, Mice, Spiders, Flies, Pigs, and Chimpanzees: How Chance Casts the Historic

Action Photograph into Doubt," History and Theory 48 (Dec. 2009): 59-76.

108 See, for example, Joel Snyder, "Res Ipsa Loquitur" in Things That Talk: Object Lessons from Art and Science, ed. L. Daston (New York: Zone Books, 2004), 195-221; Steve Edwards, The Making of English Photography: Allegories (University Park, PA: Penn State University Press, 2006), esp. 136-46; and Josh Ellenbogen, Reasoned and Unreasoned Images: The Photography of Bertillon, Galton, and Marey

(University Park, PA: Penn State University Press, 2012).

109 Walter Benn Michaels, "Photographs and Fossils," in Photography Theory, ed. J. Elkins (New York: Routledge, 2006), 442.

\section{Ibid., 432, 444}

111 See C. H. Collins Baker, Catalogue of British Paintings in the Henry E. Huntington Library and Art Gallery (San Marino, CA: Hunting

112 For this episode, see S. N. Behrman, Duveen (New York: Random House, 1952), 208-11. More recently, see Shelley M. Bennett, The Art of Wealth: The Huntingtons in the Gilded Age (San Marino, CA Huntington Library, 2013), 271-8

113 See Huntington Conservation File for 26.107 (After Joshua Reynolds, Lavinia (Bingham), Countess Spenser).

114 See [Mr. van West?] to C. H. Collins-Baker, Oct. 13, 1943, in Huntington Conservation File for 11.16 (Follower of Reynolds, Unknown Man called Richard Brinsley Sheridan). 